\title{
The Great Compression: The Wage Structure in the United States at Mid- Century
}

\section{Citation}

Goldin, Claudia and Robert A. Margo. 1992. "The Great Compression: The U.S. Wage Structure at Mid-Century." Quarterly Journal of Economics 107 (1): 1-34.

\section{Published Version}

$10.2307 / 2118322$

\section{Permanent link}

http://nrs.harvard.edu/urn-3:HUL.InstRepos:30703979

\section{Terms of Use}

This article was downloaded from Harvard University's DASH repository, and is made available under the terms and conditions applicable to Other Posted Material, as set forth at http:// nrs.harvard.edu/urn-3:HUL.InstRepos:dash.current.terms-of-use\#LAA

\section{Share Your Story}

The Harvard community has made this article openly available.

Please share how this access benefits you. Submit a story.

Accessibility 
NBER WORKING PAPERS SERIES

THE GREAT COMPRESSION: THE WAGE STRUCTURE IN

THE UNITED STATES AT MID-CENTURY

Claudia Goldin

Robert A. Margo

Working Paper No. 3817

\author{
NATIONAL BUREAU OF ECONOMIC RESEARCH \\ 1050 Massachusetts Avenue \\ Cambridge, MA 02138 \\ August 1991
}

An earlier version of this paper was presented at the NBER Conference on "Changes in the Structure of Wages," Cambridge MA, August 1990. Comments from Brad DeLong, Stanley Engerman, Lawrence Katz, NBER conference participants, and seminar participants at the Harvard Labor Studies Workshop and the Research Triangle Economic History Workshop are all gratefully acknowledged. We thank Boris Simkovich for his careful research assistance. This paper is part of NBER's research program in Labor studies. Any opinions expressed are those of the authors and not those of the National Bureau of Economic Research. 
NBER Working Paper $\$ 3817$ August 1991

THE GREAT COMPRESSION:

THE WAGE STRUCTURE IN THE UNITED STATES AT MID-CENTURY

\section{ABSTRACT}

The structure of wages narrowed considerably during the $1940^{\prime} \mathrm{s}$, increased slightly during the 1950's and 1960's, and then expanded greatly after 1970. The era of wage stretching of the past two decades has been a current focus, but we return attention here to the decade that was witness to an extraordinary compression in the wage structure. Wages narrowed by education, job experience, region, and occupation, and compression occurred within these cells as well. For white men, the 90-10 differential in the $\log$ of wages was 1.414 in 1940 but 1.060 in 1950. By 1985 it has risen back to its 1940 level. Thus the recent widening of the wage structure has returned to it a dispersion characteristic of fifty years ago.

We explore various explanations for the rapid compression in the wage structure during the 1940's and for its maintenance during the subsequent decade or more. We first assess the hypothesis that the Great Depression left the wage structure in 1939 more unequal than in the late 1920's, but we find evidence to the contrary. World War II and the National War Labor Board share some of the credit for the Great Compression. But much belongs to a rapid increase in the demand for unskilled labor at a time when educated labor was greatly increasing in number. These same factors caused the wage structure to remain compressed until its expansion during the past two decades.

Claudia Goldin Department of Economics Harvard University Cambridge, MA 02138 and NBER
Robert A. Margo

Department of Economics

Vanderbilt University Nashville, TN 37235 and NBER 
The Great Compression -- our term for the narrowing of the wage structure in the 1940's - followed the Great Depression of the 1930's and produced a wage structure more equal than that experienced since. We explore here the features of the narrowing wage structure of the 1940's, its quantitative significance compared with the recent widening of the post-1960's, and its determinants. We seek to resolve whether the 1940's were a unique decade of narrowing or whether the decade brought to the fore a set of structural changes that had been maturing for the previous hall century. In the process, we explore hourly earnings of white-collar workers to determine whether the wage structure in 1940 was anomalous, and we look at industrial wage distributions to determine the impact of World War II.

The wage structure narrowed in many ways during the 1940's. The variance in the log of weekly wages, for male wage and salary earners working more than 39 weeks in 1939, was 0.325 in 1940, but 0.259 in 1950 (see Table 1). The difference in the log of weekly wages between those at the 90th and those at the 10 th percentiles was 1.45 in 1940 but 1.06 in 1950 . Educational and skill premia plummeted, geographica! differences in wages were reduced, and the variance of wages within these groups fell substantially. When the United States emerged from war and depression it had not only a considerably lower rate of unemployment, it also had a wage structure more egalitarian than at any time since. Further, the new wage structure remained somewhat intact for several decades. According to Lester Thurow, writing in 1975: -After the wage differentials of the Great Depression and World War If had become embedded in the labor market for a number of years, they became the new standard of relative deprivation and were regarded as 'just' even after the egalitarian pressures of World War II had disappeared. Basically, the same differentials exist to this day, thirty years later $(1975, p .111) . "$

The same differentials do not exist to this day. Rather, the movement toward equality in the 1940's was reversed in the post-1970 period. In fact, remarkable similarities exist between the narrowing wage structure of the 1940's and the widening wage structure after 1970. Comparing the two periods, as we do in Table 1 , conveys a sense of the level of inequality and 
the magnitude of decline in the 1940's. The difference between the log of weekly wages at the 90th and the 10 th percentiles in 1940 was virtually identical to that in 1985 of 1.46 . For 1950 the same statistic is 1.06 , and probably no year since has produced greater equality of wages. In terms of this particular measure of the wage structure, inequality in 1940 was similar to that in 1985 and the change from 1940 to 1950 was substantial by historical standards. Inequality of income, however, should also include the unemployed. In terms of that measure, 1940 would be more unequal than 1985 , although the decrease in inequality to 1950 would be even greater. ${ }^{1}$

The wage structure, as can be seen in Figure 1 , has been on a long-run roller coaster ride since 1940 -- with inequality falling precipitously during the 1940's, rising slightly in the 1950's and 1960 's, and finally increasing sharply from the 1970's. ${ }^{2}$ The statistical properties of the initial fall and recent rise are, in many ways, mirror images of each other. Not only did the between-group variance change in comparable but opposite ways, but the decrease in the within-group variance in the 1940's was of similar magnitude to the increase in the post-1960's period.

But here the similarity between the two periods ends. Scholars have been grappling with a wide range of supply and demand factors to explain the recent widening of the between and within group variances (Blackburn, Bloom, and Freeman, 1990; Bound and Johnson, 1989; Katz and Murphy, 1990; Katz and Revenga, 1989; union and minimum wage factors are also considered in much of this literature). For the 1940's, however, unique historical events, institutional changes, and the ending of the Great Depression might explain much of the narrowing between and within groups. The 1930's and the 1940's were times of remarkable change in the economy, in the structure of wages in particular, and much may have been engineered by the government through the National Industrial Recovery Act (NIRA) and, during the war, the National War Labor Board (NWLB). Further, unemployment during the 1930's might have affected the wage structure. We explore both the residual influence of the depression and the impact of the war, in addition to the more usual influences of changing supply of and demand for skills, to resolve why the wage structure narrowed so quickly and why it remained compressed 
until the 1960's.

We are not the first to identify a compression in the wage structure in the 1940 's. ${ }^{3}$ But previous work was hampered because published census data on earnings are not comparable across census dates (Bartlett, 1978; Miller, 1955, 1958, 1966). We make use here of the recently available public use microdata samples (PUMS) of the 1940 and 1950 censuses, along with the public use sample of the 1960 census. These data permit a study of changes in the wage structure, at a highly disaggregated level, and enable us to make consistent links with more recent measures.

The reasons we offer for the substantial narrowing in the wage structure during the 1940's combine the short-run impact of wartime demand for less-skilled labor and the manner in which wartime wage changes were administered, with longer-run changes in the demand for and supply of educated workers in the 1940's. If the decade of the 1980's created the rust belt, then surely the 1940's created the steel belt. The nation's relative demand for less-educated workers soared in the 1940's. At the same time, the relative supply of educated workers rose. The initial impact was to compress the wage structure. In the longer run, the continued increase in the supply of educated workers, in the absence of a strong relative demand shift for them, held the new equilibrium in place. But it, 100 , finally gave way and the wage structure expanded greatly. That, however, is a recent chapter in the history of the wage structure (see Katz and Murphy, 1990).

1.0 The Wage Structure, 1940 to 1960: Evidence from the Census Public Use Samples

1.1 Between and Within Variance in the Wage Structure by Education, Experience, Occupation, and Region

Our sample from the 1940,1950, and 1960 PUMS consists of men between the ages of 18 and 64 employed for at least 40 weeks in the year preceding the census, who were wage or salary earners, and who earned, on average, more than one-half the minimum weekly wage. in most cases our sample consists of white men only, atthough in some instances we broaden the criteria to include all races for the purpose of comparing our results with those for the more 
recent period. The decision to limit the sample to wage and salary earners is dictated by the nature of the 1940 census, which did not include information on income from self-employment. The criteria of working at least 40 weeks and receiving more than half the minimum wage were chosen to eliminate individuals whose average weekly earnings were too low to be believed. These assumptions are, conveniently, virtually identical to those used in much of the recent work on the wage structure (e.g., Juhn, Murphy, and Pierce, 1989; Katz and Murphy, 1990).

The wage structure can be analyzed along several dimensions among which education and labor market experience have received the most attention. Accordingly Table 2 gives the ratio of weekly wages for college graduates to high school-only graduates, the ratio of weekly wages for those with some college to high school-only graduates, and the ratio of weekly wages of high school-only graduates to those who stopped their education after graduating from elementary school, for 1940 to 1960 . Unlike the other tables in this section, the sample covered in Table 2 includes all males, rather than just whites to provide exact comparability with the analysis in Katz and Murphy (1990) of the post-1963 wage structure. We have also listed the ratios given by Katz and Murphy for 1963 and 1987 . It should be noted that the ratios in Table 2 for 1940,1950 , and 1960 are about 10 percent larger than are those computed from a regression that holds constant various factors, including race and location. The trend over time and the comparisons with the more recent period are unaffected.

Although few Americans completed college in 1940 (see Table 11), the ratio of weekly earnings of college to high school graduates is examined first because it is so often used for the post-1960's period. The ratio was considerable in 1940, particularly for men with fewer than 21 years of labor market experience, and its level, at about 1.6, was about equal to that achieved in 1987. There is a sharp drop-off in the ratio of weekly earnings for college to high school graduates at 21 years of experience, although only a small fraction of the college-educated sample was in that range. Measured across all experience groups (not given in the table), there was a 13 percentage point decline in the premium to college over high school graduation 
between 1940 and 1950. The college graduation premium increased during the 1950's, but was still lower overall in 1960 than in $1940 .^{5}$ The decline in the premium during the 1940's was concentrated among men with fewer than 21 years of work experience, for whom the decline was about 30 percentage points, while the increase in the 1950's occurred for men in all experience groups. $^{6}$

Although there are some differences by experience group, the overall college graduation premium in 1960 is very similar to the estimate for 1963 from Katz and Murphy (1990). The close similarity of the overall ratios in the 1960's bolsters confidence in comparisons across the entire period, 1940 to 1987 . Such comparisons reveal a narrowing in the wage structure from 1940 to 1950 and a subsequent widening from the 1950's to 1987. For example, among those with 11 to 15 years of experience the decline from 1940 to 1950 was 31.5 percentage points, the rise from 1950 to 1960 was 10.3 points, and that from 1963 to 1987 was 5.1 points. For the 6 to 10 year and 16 to 20 year experience groups, a decrease from 1940 to 1950 of between 24 to 36 percentage points was offset by an increase of almost equal magnitude from 1950 to 1987 . Thus the rise in the college to high school graduation premium during the 1980's has returned it to the level it achieved on the eve of World War II.

Similar patterns are apparent in the relative wages of workers with some college and for the high school graduate premium, atthough the changes are attenuated compared with those for college graduates. As in the college graduate results, there is a decline from 1940 to 1950 and a subsequent rise, but generally not large enough to revert the ratio to its previous level.

Occupational premia were also compressed during the 1940's, as can be seen in Table 3. Relative to all non-farm workers, professional wage earners lost 20 percentage points or 14 percent, while laborers gained 13 percentage points or 21 percent. Operatives and service workers also gained somewhat compared with all non-farm workers.

The census evidence presented thus far pertains to changes in relative wages between groups by education, experience, and occupation. Table 4 reveals another component to 
change, that within educational, experience, and occupational groups.

The difference between the log of weekly wages at the 90th and the 10th percentiles declined for all educational groups between 1940 and 1950 (Table 4, part A). While there was some recovery to 1960 , the increase was rather modest. Further, the decrease during the 1940 's within each of the educational groups was remarkably similar, with the exception of the least educated. Within each of the groups having 8 or more years of schooling the wage structure narrowed by 31 percent to 39 percent. That is, the difference in the log of the wage at the 9oth and the 10th percentiles was about 1.34 in 1940 but around 0.99 in 1950, and there is only slight variation across the educational groups.

Rather similar results are found in the data by experience group (Table 4, part B). The difference from 1940 to 1950 in the $90-10$ percentile measure is 32 percent to 50 percent, with the exception of those having the least experience. As in the education results, the narrowing of the wage structure within each of the groups is seemingly independent of the level. The final panel (part C) gives similar measures for various occupational groups. All reveal a substantial decrease in within-group variance from 1940 to 1950 with modest recovery to 1960 . The withingroup dispersion decreased most for white-coliar workers, where the decline was 32 percent. But it also decreased for craft workers (25 percent), operatives (23 percent), and laborers ( 8 percent). As in the previous tables showing the between group variance, Table 4 reveals not only that there was a decrease in the 1940's but also that the decline was from a very high level.

Table 5 looks within two regions, the poorest and for comparison the most established, by educational group. Considering white males only, the South had a substantially wider wage structure in 1940 than did the Northeast, although both experienced compressions of comparable magnitude. Although the compression was somewhat smaller among the higher educated in the South, its magnitude was invariant to educational level in the Northeast. Once again, any explanation offered for the compression in the wage distribution from 1940 to 1950 must take into account that the narrowing within groups appears to be largely independent of the levels of 
education and experience.

Finally, Table 6 examines the distribution of the residuals from a wage equation that includes most of the factors just examined, with the exception of occupation. The residual distribution is an indication of the within-group variance, and thus the change in its distribution indicates alteration in the within-group variance. From 1940 to 1950 there was an increase at the lower end of the residual distribution and a decrease at the upper end, with the exceptions of the lowest and highest one percentiles. The change, once again, is an almost mirror-image of that from 1963 to 1987 (Katz and Murphy, 1990, figure 2, part B). A conclusion from Table 6 is that the decrease in the within-group variance, as in Table 4, is not an artifact of failing to control simultaneously for the effects of education, experience, region, and so on, or from focusing on particular centiles of the wage distribution. Rather, there was a decline in the within-group variance that cannot be explained entirely by the factors considered thus far.

\subsection{Decomposing Change in the Wage Structure}

To further investigate change in the wage structure over time, we follow Juhn, Murphy, and Pierce (1989) and construct a decomposition based on the standard wage equation:

$$
y_{i t}=X_{i t} \beta_{t}+\mu_{i t}
$$

where $y_{i t}=$ the log of weekly wages for individual $i$ in year $t, X_{i t}=$ individual characteristics that affect weekly wages, and $\beta_{\mathrm{h}}=$ the implicit prices or values for these characteristics. Assume that the error term in equation (1) contains two components and takes the form:

$$
\mu_{\mathrm{it}}=\mathrm{F}^{\cdot}{ }_{\mathrm{t}}\left(\Phi_{\mathrm{it}} \mid \mathrm{X}_{\mathrm{it}}\right)
$$

That is, individual $\mathrm{i}$ occupies some position or percentile in the distribution of residuals for year $t, \phi_{n}$, and each year has a particular inverse cumulative distribution of residuals, $F^{-1}\left(\cdot \mid X_{n}\right)$. Framed in this manner, the percentile occupied by each individual and the distribution function for each year can be varied independently. An individual's position in the residual distribution function is a function of the individual's characteristics, the $X$ 's, while the distribution function itself depends on unobservable factors. Changes in the wage structure can then be decomposed into 
three factors - changes in the quantities of skills (the X's), changes in the prices of skills and other variables (the $\beta$ 's), and changes in unobservable factors that get swept into changes in the distribution of residuals.

The virtue of the technique is that it reveals how the full distribution of wages changes as quantities and prices are successively changed. A complication is that there is no unique decomposition, and the procedure may be sensitive to the order of the changes as well as to the base-year weights employed. We compute the technique in several ways to test the robustness of the findings.

Intuitively, one computes the full distribution of wages for some base year, say 1940, and from this distribution various summary statistics, such as the difference in the log of wages at the 9oth and the 10 th percentiles. A hypothetical experiment is then conducted which consists of changing the characteristics (the X's) of individuals. The full distribution of the resulting wages is then computed and from this, the summary statistics. The difference between, say, the 90-10 measure for the actual distribution and that in the hypothetical world of changed quantities, is allotted to movements in quantities. The next step is to change both prices and quantities and allocate the incremental change to prices. Finally, the total change in the $90-10$ measure minus that due to prices and quantities is assigned to changes in the residual distribution. Note that both the base year and the order of the decomposition are arbitrary.

Formally, and for the case of a 1940 base year, a predicted log wage, $y_{1}$, is computed for each individual in 1950 with coefficients from the 1940 regression and a residual that takes the individual's position ( $\phi$ ) from the residual distribution of 1950 but assigns the corresponding residual value from the 1940 distribution:

$$
y_{1}=X_{50} \beta_{40}+F^{-1}{ }_{40}\left(\phi_{50} \mid X_{50}\right)
$$

The only change between the hypothetical $y_{1}$ of equation (3) and the actual $y_{1980}$ concerns the characteristics (the $X ' s)$. Next, change both the $X$ 's and the $\beta$ 's:

$$
y_{2}=X_{50} \beta_{50}+F^{-1}{ }_{40}\left(\phi_{50} \mid X_{50}\right)
$$


In the case being considered, $y_{2}$ will have a more compressed distribution than $y_{1}$, and the increment to the compression is allocated to the factor that has changed between equations (3) and (4), the $\beta$ 's. That is, comparing the distribution of $y_{2}$ with that of $y_{1940}$ reveals how both prices and quantities affect the distribution of wages. The final step is to subtract the total of the changes, that is the particular summary statistic of the distribution of $y_{2}$, from the total change over the two years. That difference is allocated to the change in the residuals.

Table 7 shows the decrease in the wage spread from 1940 to 1950 using three summary measures of the wage distribution, calculated from data in Table 1. Using the 90-10 percentile measure, the change was a decrease of 0.354 , that is a 35.4 percent decrease in spread. There was a 20.2 percent decrease in the $90-50$ percentile measure, that is from the median to the high end of the distribution, and a 15.3 percent decrease in the 50-10 percentile measure, that is from the median to the low end.

The decomposition reveals the importance of changes in prices over the two periods, although quantity changes are almost as important using 1950 base weights. Price changes, however, overwhelm quantity changes using 1940 as the base year. The choice of base year greatly affects the importance of changes in the distribution of residuals relative to changes in both prices and quantities. When 1950 is the base year, the residual distribution has virtually no impact on the total change, while it accounts for about 60 percent when 1940 is the base year. Atthough the decomposition does not yield unambiguous results on the relative importance of the residual distribution, it provides a clear statement on the role of the prices of skills. The returns to schooling plummeting during the 1940's and that factor was responsible for about 45 percent of the compression in the wage structure. ${ }^{7}$ What ultimately caused the price of skill to decline is the subject of the next section. 


\subsection{Explaining the Great Compression}

The compression in the wage structure from 1940 to 1950 may have been caused by factors unique to the World War II period or, alternatively, may have been a continuation of secular forces disrupted during or accelerated by the Great Depression. Although the pre-1940 evidence is slender, wages of manufacturing operatives and craftsmen show a decline in the skill differential. Similar findings for the earnings of the upper portion of the income differential also suggest a pre-1940 decrease in inequality. These data, therefore, imply that the compression of the 1940's was a continuation of secular forces. But the decline before 1940 was considerably smaller in magnitude than that during the 1940's, and the Great Compression was not, in any way, a simple extrapolation of what came before.

Further, we present below new data on white-collar earnings that reveal, when compared with wages for unskilled labor, an absence of a pre-1940 compression in the skill differential. The series even suggest a widening in the returns to skills, such as education, during the 1920's. Therefore, even though the ratio of skilled manufacturing workers to unskilled manufacturing workers may have declined prior to 1940 , the return to education may not have begun to narrow until the 1940's.

Our white-collar wage series reveals another factor of importance to this study. Because unemployment during the Great Depression was disproportionately borne by the least educated and the lesser skilled, one might be suspicious of the earnings data for 1939 (from the 1940 census). But the new series demonstrates that 1939 was not anomalous. Although inequality widened at the beginning of the 1930's, it narrowed after 1933, probably because of the minimum wages of the National Industrial Recovery Act (NIRA). Most series we have uncovered show little overall change from 1929 to 1939 , atthough the wage structure changed within the decade.

Because the wage structure in 1939 was not anomalous, we are led, therefore, to factors unique to the World War II period to explain much of the initial compression. The National War Labor Board may have engineered a large portion the narrowing during the first half of the 
decade. Evidence from a host of industry wage structures, spanning the late 1930's to the early 1950 's, reveals that compression during the 1940's was not confined to the period before V $\checkmark$ Day. The introduction and expansion of the minimum wage had some impact, but cannot explain the compression in the wage structure at the upper end of the distribution. Further, atthough the wage structure widened somewhat after 1950, it remained considerably more compressed than before the war. To explain the persistence of the command economy wage structure we return to educational changes which increased the supply of more skilled workers and to demand-side influences which buoyed the relative pay of the lesser skilled.

\subsection{Long-Run Factors Affecting the Wage Structure}

Historical statistics have not been kind to scholars interested in the wage structure. The 1940 census was the first to inquire into the earnings and education of Americans, and before that date no comprehensive data exist that include information on education and earnings. Information is available, however, to produce occupational wage ratios across long periods of time. The numerator of the pay ratio has most often been the wage of skilled artisans, typically in the building trades but also skilled craftsmen in manufacturing. The denominator has often been that of "common laborers," but also janitors, helpers, maintenance workers, hand truckers, and manufacturing operatives, particularly in the twentieth century.

Williamson and Lindert (1980; hereafter $W \& L$ ) have linked various series to produce a composite series of pay ratios between artisans and laborers extending from the earty nineteenth to the mid-twentieth century. Portions of their linked series for the twentieth century are given in Table 8 , together with a series (National Industrial Conference Board, NICB, column 1) that underlies their index, one due to Ober (1948) and Miller (1966), and another to the BLS (column 3). The data show a slow secular increase in the pay ratio of the skilled to the unskilled until about 1925, with the exception of an important decrease during World War I. From 1925 to 1948 the ratio declined by 10 percent. But, measured in logs, about two-thirds of the decline occurred 
during the 1940's. Widely cited series constructed by Ober and Miller, from data for the building trades, show a more continuous narrowing from 1907 to 1940, and a much steeper decline from the late 1940's to the early 1950's (Table 8; see also Keat, 1960). The discrepancies between the W\&L linked and the Ober and Miller series can partly be traced to differences in the underlying data. $^{B}$

Further evidence that the narrowing of the wage distribution began before 1940 but accelerated after is found in the works of Kuznets (1953) and Goldsmith (1967) on the income distribution. Both studies use Internal Revenue Service data. The Kuznets series for the share of income received by the top 5 percent shows a decrease from about 30 percent in the 1920's to 28 percent in 1939 . It falls to 26 percent by 1941 and plummets to just below 20 percent in 1946. The Goldsmith measure indicates a somewhat larger proportion of the decline occurred in the 1930's.

If the secular forces that operated to narrow skill differentials were those that increased schooling, then neither of the wage series just examined is very useful, since both are concerned with skill differentials between blue-collar occupations. Neither is the Kuznets or Goldsmith evidence very illuminating since they concern just the very top of the income distribution. It is natural to ask whether pay ratios for white-collar workers, such as professionals and clerical workers, show evidence of decline during the first half of the twentieth century.

Existing evidence for white-collar workers presents a somewhat confusing picture of inequality changes over long periods of time. The data are often for public-sector employees (e.g., teachers), or for self-employed professionals (e.g., doctors, lawyers) whose hours cannot easily be held constant over periods of economic downturn. The ratio of teachers' earnings to those of unskilled non-farm laborers decreased substantially in the 1930's, narrowed slightly in the 1940's, but widened since. Data for physicians relative to those for manufacturing operatives reveal an upward, not a downward, trend from the early twentieth century, with some narrowing during the Great Depression. Associate professors' salaries show a clear long-run relative 
downward trend, with the greatest compression during the 1930 's. ${ }^{9}$ A major problem with the available white-collar pay ratios is that the data on professional incomes are rarely adjusted for cyclical variations in hours or weeks worked, while the data for unskilled labor (the denominator) are. When ratios are adjusted for such cyclical variations, the decline in relative professional pay in the 1930's, while present, is much smaller.

2.2 New Evidence on the Skill Differential and White-Collar Earnings, 1920's to 1950's

Evidence on the eamings of white-collar workers is required to assess whether the compression in the wage structure we observe in the 1940's was a continuation of a longer-term secular movement or a product of more recent vintage. Because white-collar workers reap the returns to education, while those who are unskilled workers in manufacturing do not, we have constructed two series for clerical-worker wages, given as ratios to unskilled workers in Table 8. (These series are described in detail in an Appendix, "Skill Ratios and Wage Distributions: 1920's to 1950 's.") That in column (4) is the ratio of the hourly (or monthly) wage of clerks hired by class-l steam railroads to the hourly (or monthly) wage of laborers, also hired by these railroads. That in column (6) is the ratio of the weekly earnings of male clerks working in factories in New York State to the weekly earnings of unskilled manufacturing workers. All series move together, although change is greatest for the ratio using NYS clerks, which is unadjusted for hours. The three are graphed in Figure II.

The series on clerk to unskilled wages show some gain during the 1920's. But the interesting changes appear as the depression quickly worsened after 1929. Clerical wages rose immediately relative to unskilled. From 1929 to about 1934 the increase in the ratio was 8 percent for railroad workers on an hourly basis, 26 percent on a monthly basis, and 31 percent for the NYS cierical workers on a weekly basis. There is considerable evidence, therefore, that on an hourly basis the educated gained relative to the lesser educated during the early years of the Great Depression. And the educated gained far more on a weekly basis, as their hours declined 
less than did those for the employed lesser-skilled worker. Hours of laborers decreased by 26 percent and those of machinists by 30 percent, while those of clerks decreased by only 5 percent from 1929 to 1932 or 1933 (see also Bernanke, 1986; the Appendix contains further details on hours).

But the relative gains experienced by clerical workers were short-lived. Some time between 1933 and 1934 , depending on the series, the gains they made were eroded, and the likely reason is the setting of minimum wages and maximum hours by the National Industrial Recovery Act (NIRA), passed June 1933 (see Weinstein, 1980, on the NIRA). But the NIRA itself was short-lived, and there is no apparent increase in the ratio after the NIRA was declared unconstitutional in May 1935. Quite possibly economic recovery reversed the immediate impact of the depression on the skill differential.

\subsection{Was 1939 Anomalous?}

Prior to the construction of the series just described, there was ample reason to believe that wages of the less-educated in the late 1930's had been dampened by a "reserve army" of private-sector unemployed. Data from the 1940 census sample reveal that unemployment rates were considerably higher among less-educated workers, and were U-shaped with respect to labor market experience. ${ }^{10}$ According to some scholars, the availability of large pools of unemployed workers, particularly less-skilled and less-educated labor, put downward pressure on wage rates in the late 1930's (Baily, 1983). Because the unemployed were disproportionately less-educated, the "reserve army" effect arguably could have widened the wage distribution in 1939.

But by 1939, the year to which most 1940 census data refer, the skill ratios in Table 8 , columns (4) and (6) had returned to their approximate values in 1929, despite the fact that they had widened, often significantly, during the depression. That is, 1939 does not appear anomalous in terms of the premium to educated labor. Nor, in fact, does it appear anomalous in terms of the premium to skilled labor, as in the case of railroad machinists whose hourly wages 
also rose relative to railroad laborers during the early years of the depression. We should emphasize that our views concerning the rebound in the relative wages of the unskilled during the last half of the 1930's is based on two new series for educated labor. Further evidence may lead us to revise this conclusion. But there are no currently available wage series based on large samples that indicate the wage structure was anomalous in 1939 in comparison to the late 1920's. If anything, the previously used series (based on the NICB data) indicate virtually no change at all during the Great Depression.

In sum, the premium to skill, particularly to that associated with schooling, does not appear to have declined prior to the 1940's. In fact, there is some evidence that it widened during the 1920's and fluctuated, with no permanent change, during the depression. The skill premia for both educated and trained labor returned to its pre-depression levels by 1939 . It should also be noted that the clerical data reveal that the ratio of hourly earnings of clerks to laborers continued to decline even after 1945, reaching a level just above 1.2 in $1952 . "$ Because we can be fairly confident that the wage structure observed using the 1940 census had not been stretched considerably during the depression, we can venture to ask what caused it to be compressed during the 1940's.

\subsection{World War II and the National War Labor Board}

Any explanation for the Great Compression of the 1940's must closely examine the impact of World War II and the command economy that accompanied it. Even though the war probably increased the demand for less skilled relative to more skilled and educated labor, firms could not simply increase wages to attract labor. The National War Labor Board (NWLB), established in January 1942 and dissolved in December 1945, was responsible for approving all wage increases and decreases after the Stabilization Act (also known as the Price Control Act) of October 1942 made any wage change illegal without its approval. During its brief lifetime, it and its regional agencies processed 463,000 applications for wage increases and ruled on 70,000 cases of 
possible violation of the Stabilization Act (U.S. Department of Labor, 1949).

Given its limited staff, the NWLB made decisions based on rules of thumb concerning wage increases in war and nonwar industries. One of these, known as the "Little Steel Formula," was decided in July 1942, before the NWLB obtained expanded powers under the Stabilization Act. Steel employees were granted a small wage increase on equity grounds, but a larger -- 15 percent -- increase to adjust for cost of living changes from January 1941 to May 1942. With "Little Steel," any wage could rise by 15 percent over its January 1941 level. Although "Little Steel" could not affect the wage structure, other rules of thumb did. Wages could be increased to 40 cents per hour without the NWLB's approval and up to 50 cents per hour with approval of the Regional NWLB, following President Roosevelt's directive to increase substandard wages (Rockoff, 1986, p. 119). Ranges of wages, called "brackets," were established for each occupation, and wages could be raised to the lower end within any bracket. The NWLB also allowed increases that eliminated intraplant differences in wages by occupation. Finally, the NWLB, following its mandate to assist in "the effective prosecution of the war," allowed certain wage increases in war-related industries (see Rockoff, 1986 for a more complete discussion). Most of the criteria for wage increases used by the NWLB served to compress wages across and within industries. To be sure, firms found ways to circumvent wage stabilization - the payment of benefits rather than wages and the upgrading of workers into better-paying jobs, were two. But exceptions to controls, it was often noted, were more frequently granted to employees receiving "substandard" wages. ${ }^{12}$ Thus the NWLB may have served to compress the wage structure significantly.

Industry studies done by the Bureau of Labor Statistics from the late 1930's to the early 1950 's are used here to assess precisely when the wage structure was compressed during the 1940's. We had inferred a narrowing of the wage structure during the 1940's from census data on earnings in 1939 and 1949, but such data cannot reveal the precise role of World War II. Although the war could have served to narrow the wage structure through the operation of the 
National War Labor Board, a subsequent widening could have accompanied the dismantling of controls. Alternatively, the wage structure could have changed in both periods or in the postWorld War II period but not during the war. The fact that the wage structure did not quickly return to its pre-World War II configuration for more than fifteen years after the war, is prima facie evidence that various forces served to reinforce the impact of the command economy. The existence of a vast number of BLS reports enables a fuller understanding of the role of Worid War II and the NWLB. The reports contain wage distributions by industry, and often within industry by region, sex, and skill. Many were background reports for legislation on the minimum wage, which was increased four times from its inception at 25 cents with the Fair Labor Standards Act of October 1938 to January 1950, when it was increased to 75 cents. $^{13}$ It was increased to 30 cents in October 1939 and again in October 1945, just after the war, to 40 cents.

The BLS surveyed more than 70 (at about the three-SIC-digit level) industries from the late 1930 's to the early 1950 's, but only fitteen industries contain comparable information for two periods during the time interval. These data are summarized in Table 9, (see the Appendix for the actual numbers and for more complete documentation). For only three industries (cotton textiles, fertilizer, and foundries) are there wage distributions for the pre-war (1936 to 1941), war (1942 to 1946), and post-war (1947 to 1952) periods. For all other cases there are two observations, most covering the pre-war to war or war to post-war periods. From these we can make inferences about the timing of the wage compression and its causes. The dating of the prewar, war, and post-war periods is meant to capture, first, the wage distribution before the National War Labor Board, next the distribution after its rules took effect, and later still, the wage structure when firms had adequate time to respond to the dismantling of controls.

The main finding is that wage compression in the upper range of the distribution (measured by the difference in the log of the wage at the 90th and 50th deciles) occurred during the war and continued long after wage controls ended, a finding from the clerical data as well. Compression in the lower portion of the distribution (from the 10th decile to the median) was 
generaliy strong in the pre-war to war period but less strong in the war to post-war period, despite the continuing rise of the minimum wage. On net, the more inclusive measure of the wage distribution (the difference in the log of wages at the 90th and 10th deciles) mirrors the large changes in the upper tail, and the notion that the wage structure experienced compression during both the war and post-war periods is upheld.

The exceptions to the general trends just mentioned are instructive. Industries that were female-intensive (cigars, men's neckwear, woolen and worsted milis) comprise an obvious exception. Rather than experiencing a narrowing of the wage structure from the pre-war to the war-time or post-war periods, their distributions actually widened. Wages in these industries, like so many that are female-intensive, were extremely low and contained little dispersion prior to the war. War-time demand increased women's wages relative to men's and led to an increase, not a decrease, in wage dispersion among workers in female-intensive industries. Also of interest are the southern industries, among which sawmills and the lumber industry experienced general wage expansion, particularly in the 50-10 range. Because so many workers in these industries were at or near the minimum wage in particular years, change in the lower portion of the wage structure is highly dependent in the date of the survey. It should be noted, however, that there was a narrowing in the wage structure for southern lumber in the 90-50 range from the war to post-war periods, and thus it, too, seems to follow the overall trend.

Explanations for the wage compression that rely on the activities and impact of the NWLB would imply that war-related industries had less compression from the pre-war to war periods and that low-wage industries had more compression, particularly if the initial wage distribution was highly dispersed. The BLS data do not enable a test of the hypothesis regarding war-related sectors. Although workers in private shipyards did experience wage compression, the industry grew by such an enormous factor that the character of the work force may have been completely altered. Chemicals, rubber, fabricated metals, and transportation machinery - the main war-time industries -- are not represented in the pre-war sample. ${ }^{14}$ The hypothesis concerning the lower 
wage industries, particularly with regard to those having the most dispersion, does seem correct. The greatest declines were in textiles, a low wage industry, and foundries, in which a large proportion of the work force was below the 55 cent hourly wage eventually allowed by the NWLB.

The evidence from the BLS reports, therefore, reinforces the notion that World War II and, possibly, the NWLB had large effects on the wage structure but that compression continued long after the war. Further, wage compression during the war now appears more complicated than suggested by a simple application of the rules of thumb used by the NWLB, which allowed wage increases at the lower end of the distribution. The upper tail of the distribution, even in relatively high wage and non-war related industries, also narrowed considerably during the war. This fact, in combination with the relative stability in the wage structure from 1949 to 1959 , bolsters the notion that market forces increased the demand for less-skilled manufacturing workers on a continuing basis from the 1940's to the early 1960's and served to keep in place a wage structure that was initially necessitated by the wartime economy and mandated by the command economy. This conclusion leads us to consider the roles of a changing demand for educated labor given fixed technology and the role of a changing supply of educated labor.

\subsection{The Demand and Supply of Educated Workers, 1940 to 1980}

We first analyze the demand for educated workers by holding constant, at its 1960 value, the proportion of the labor force, by industry, that achieved a particular level of schooling and varying employment by industry over the years. The findings are summarized in Table 10. Not surprisingly, the demand for white male workers with more than 12 years of schooling increased faster than that for white male workers with less than 13 years of schooling for all four decades. But the difference between the two rates was never closer than it was in the 1940's. The ratio of the growth rate for those with some college to those without any college was 1.02 in the 1940's, but it was 1.77 in the 1950 's, 1.88 in the 1960's, and then fell to 1.13 in the 1970 's.

The supply of educated Americans is given in Table 11, in which we consider only the 
1940 to 1960 period. Across all age groups in the 1940's, the growth in high school graduates exceeded that for college graduates. But, using the two educational groups of Table 10, the relative supply of the college educated expanded greatly. Thus wage compression in the 1940's between the lesser and more educated groups is no mystery. ${ }^{15}$ Relative demand stayed virtually constant while relative supply decreased. In the 1950's the supply of college-educated workers continued to increase faster than that of less-educated workers while the growth in the relative demand for the more educated greatly exceeded that for the less educated. These effects continued into the 1960's and the wage compression of the 1940's eventually began to unravel.

Not only did schooling levels change over the period, but there are also good reasons to believe that schooling variance across the United States fell during the first half of the century. Urbanization, the centralization of school districts, the school bus, and the widespread creation of publically-financed high schools greatly expanded educational options. Steady growth of landgrant and other public colleges and universities created new opportunities for high school graduates to continue their education. Regional variation in the quality of elementary and secondary education -- as measured, for example, by the length of the school year or teacher/pupil ratios -- was smaller in 1950 than in 1900 or $1930 .^{16}$ Compulsory education and child labor laws raised the opportunity costs (to parents) of keeping children out of school, and by the end of the 1920's virtually every state had passed legislation restricting child labor. The decrease in spatial variability in the quality of educational opportunities ought to have narrowed the wage spread within educational groups and may be responsible for some of the compression within groups that is observed. ${ }^{17}$

\subsection{Conclusion}

During the past quarter century wages in the United States have become more unequally distributed. Yet for the previous quarter century wage compression, rather than wage stretching, was the rule. While some data indicate that the narrowing of the wage and income distributions 
began much earlier, evidence presented here suggests that returns to schooling may not have been reduced until the 1940 's. The Great Compression, as we have called it, was primarily the result of a particular confluence of short-run events affecting the demand for labor and of institutional changes brought about by the war and the command economy that accompanied it. But the wage structure did not immediately rebound to its pre-war level, as it had after a similar decrease in skill ratios during World War I. Nor did the wage structure by industry stop narrowing when World War II ended. Rather, compression was observed at the industry level during the period from the mid-1940's to the early-1950's, and the compression occurred in both the upper and lower tails of the distribution. Several factors served to reinforce the immediate effects of the war. The relative demand for fess-educated worker increased during the 1940's and 1950's, and a rising minimum wage continued to pull up the bottom of the wage distribution. Finally, and perhaps of most importance, increases in the supply of educated labor served to depress the price of skilled labor and retained, for some time, the egalitarian impact of the Great Compression. It is perhaps not surprising that wage expansion eventually occurred for the wage structure that emerged in the 1940's may not have been a long-run equilibrium. 


\section{ENDNOTES}

1. Unemployment in 1939, the year to which the 1940 census refers, was 17.2 percent of the civilian labor force and in 1940 it had declined to 14.6 percent (U.S. Bureau of the Census, 1975 , series $\mathrm{D}-86$ ). Note that the unemployment figures do include individuals on work relief. In 1949 unemployment was 5.9 percent of the civilian labor force.

2. The roller coaster analogy may be more appropriate to describe the time series of the returns to education, since the returns decreased in the 1940's, rose somewhat in the 1950's, fell in the 1970 's, and then rose sharply in the 1980's.

3. See also Kuznets (1953) and Goldsmith (1967) on earnings. The earnings structure, as measured by the proportion earned by the richest 5 percent, began to decline during the 1930's and narrowed far more substantially during the 1940's.

4. We also impute earnings for those who were top-coded at 1.4 times the top code, although there were very few individuals who were top-coded in the 1940,1950, and 1960 PUMS. One-half the minimum wage in each of the three years is: $\$ 6$ for $1940, \$ 8$ for 1950 , and $\$ 20$ for 1960 .

5. Using data from published census tables on earnings by education groups Miller (1966) found no decline in the college graduation premium between 1940 and 1950 . Bartlett (1978) criticized Miller's conclusion, on the grounds that the 1940 and 1950 tables were not comparable. Using the 1970 PUMS, Bartlett constructed consistent pairwise comparisons between 1970 and published earnings tables for 1940,1950 , and 1960 . She found higher returns to schooling in 1940 than 1970, but similar returns in 1950 and 1970. From these comparisons, Bartlett concluded that the returns to schooling must have fallen between 1940 and 1950, but she was unable, at the time, to substantiate the conjecture directly. Our regression results, based on the 1940 and 1950 PUMS, confirm Bartlett's conjecture.

6. The sharp decrease in the premium to college graduation with men having more than 20 years of experience may be related to a change in the quality of college education in the 1920's. Note that the same drop-off is apparent in the data for 1950, except that it occurs for men with more than 30 years of experience. Another possible explanation has to do with sample selection bias. Our sample contains onfy wage and salary earners, but college graduates were disproportionately self-employed. Further, college graduates were more likely to be seff-employed at older ages and probably had higher incomes than the average college graduate. In the 1940 census, for example, 12 percent of the non-farm group were self-employed, 24 percent of college graduates were self-employed, and 33 percent of college graduates 45 years old and older were. By omitting the self-employed (by necessity, since the 1940 census does not have income from selfemployment), we could bias downward the returns to college among the older group.

7. A variance decomposition also reveals that the decrease in the variance in the residual accounts for about 30 percent of the total change in the variance of (the log of wages. The variance decomposition also indicates that changes in prices, not quantities, are responsible for the compression in wages.

8. The W\&L linked series, from 1921 to 1948 , comes from data coliected by the National Industrial Conference Board (Beney, 1936; U.S. Bureau of the Census, 1975). The NICB distinguished between two groups: skilled and semi-skilled manufacturing workers, and unskilled manufacturing workers. Unskilled workers were in jobs requiring no previous work experience, while the semiskilled and skilled (the numerator) were workers in all other positions. Clerical, sales, executive, 
and managerial personnel were excluded. Thus the NICB data yield, in effect, pay ratios between craftsmen and operatives in manufacturing. Evidence from the 1940 and 1950 public use census samples suggests little change in the ratio of craft to operative wages between 1940 and 1950 , consistent with the NICB data. In simulations of their general equilibrium model for the period 1929 to 1948 , Williamson and Lindert substituted a pay ratio for 1951 for the 1948 NICB datum, believing that the 1948 ratio was too high. The 1951 pay ratio, constructed from the BLS Area Wage Surveys, refers to mechanics, electricians, and carpenters in the building trades for the skilled group, and janitors and custodians, for the unskilled. There is no empirical basis for substituting the 1951 for the 1948 ratio. The two data sources do not overlap and, in any event, cover entirely different occupations. The only rationale could be that the Ober and Miller series shows a greater decrease than the NICB series.

9. The teacher, physician, and Associate Professor series are reproduced in Williamson and Lindert (1980) from U.S. Bureau of the Census (1975).

10. In the 1940 sample of white males, 18 to 64 years old, unemployment rates that include persons on work relief arrayed by educational attainment yield:

$\begin{array}{lc}\text { Years of schooling } & \begin{array}{c}\text { Percentage Unemployed } \\ \text { (or on work relie) }\end{array} \\ <8 & 21.0 \% \\ 8 & 17.6 \\ 9-11 & 17.6 \\ 12 & 15.3 \\ 13-15 & 10.1 \\ 216 & 6.2\end{array}$

A U-shaped pattern of unemployment with respect to experience (age - years of school - 6) is revealed by linear probability regressions in which the dependent variable takes the value of 1 if the person was unemployed (or on work relief), 0 otherwise. In addition to experience, the regressions include dummy variables for region, urban status, marital status, and household headship. Separate regressions were estimated for each educational group.

11. BLS survey data also show smaller increases in nominal hourty earnings of white-collar workers between 1941 and 1944 than of manufacturing operatives or common labor (U.S. Department of labor, 1944, p. 1048). Increases in weekly earnings in manufacturing were greater still because the percentage increase in weekly hours was more in that sector than elsewhere, and because a disproportionate share of the increase in manufacturing hours was compensated at overtime rates.

12. See Ober (1948, p. 132) on the general issue. Data from a special census survey in 1944 reveals that occupational shifts were greater among less-skilled and less-educated groups (Wool and Pearlman, 1947, p. 141).

13. Minimum wage legislation from its inception to January 1950 can be summarized as follows:

$\begin{array}{lllcl}\begin{array}{l}\text { Effective Date } \\ \text { of Minimum Wage } \\ \text { Change }\end{array} & \begin{array}{l}\text { Nominal } \\ \text { Minimum } \\ \text { Wage }\end{array} & \begin{array}{l}\text { Percent of } \\ \text { Employees } \\ \text { Covered }\end{array} & \begin{array}{c}\text { Minimum Wage/Average Hourly } \\ \text { Wage in Manufacturing } \\ \text { Before After }\end{array} \\ \begin{array}{l}\text { Wo/24/38 } \\ 10 / 24 / 39\end{array} & \$ 0.25 & 43.4 \% & & 0.403 \\ 1 & 0.30 & 47.1 & 0.398 & 0.478\end{array}$




$\begin{array}{lllll}10 / 24 / 45 & 0.40 & 55.4 & 0.295 & 0.394 \\ 1 / 25 / 50 & 0.75 & 53.4 & 0.278 & 0.521\end{array}$

Source: Ehrenberg and Smith $(1991$, p. 83$)$.

14. Wage structure data exist for foundries in all three periods, although different types of foundries are included in each. Changes in foundry wage structures do not appear different from those in non-war related industries. That is, there does not seem to have been more growth in the upper tail of the distribution.

15. Although we have highlighted the wage compression between high school graduates and college graduates, Table 2 also reports enough information so that a wage compression between the college educated and those without college is also evident for the 1940's.

16. The coefficient of variation, for 1900,1930 , and 1950 , across states in the length of the school year and in pupil-teacher ratios (public schools only) were

$\begin{array}{lrcc} & 1900 & 1930 & 1950 \\ \text { Length of term } & 23.9 & 7.6 & 3.1 \\ \text { Pupil-teacher ratio } & 132.8 & 18.7 & 14.1\end{array}$

Source: U.S. Bureau of Education (1901), U.S. Department of the Interior (1932), U.S. Department of Health, Education and Welfare (1954).

17. Card and Krueger (1990) demonstrate that long-term increases in school quality (e.g., teacher/pupil ratios) have a positive effect on earnings by raising the rate of return to schooling. 


\section{REFERENCES}

Baity, Martin. (1983) "The Labor Market in the 1930s." In James Tobin, ed. Macroeconomics, Prices and Quantities: Essays in Honor of Arthur Okun. Washington, D.C.: Brookings Institution.

Bartlett, Susan. (1978) "Education, Experience, and Wage Inequality: 1939-1969," Journal of Human Resources 13 (Fall): 349-65.

Beney, M. Ada. (1936) Wages, Hours, and Employment in the United States, 1914-1936. New York: National Industrial Conference Board.

Bernanke, Ben. (1986) "Employment, Hours, and Earnings in the Great Depression: An Anatysis of Eight Manufacturing Industries." American Economic Review 76 (March): 82-109.

Blackburn, McKinley, David Bloom, and Fichard B. Freeman. (1990) The Declining Position of LessSkilled American Males." In Gary Burtless, ed. A Future of LousY Jobs?: The Changing Structure of U.S. Wages. Washington, D.C.: The Brookings Institution.

Bound, John and George Johnson. (1989) "Changes in the Structure of Wages During the 1980s: An Evaluation of Alternative Explanations." National Bureau of Economic Pesearch Working Paper No. 2983.

Card, David, and Alan Krueger. (1990) "Does School Quality Matter? Returns to Education and the Characteristics of Public Schools in the United States," Paper prepared for the NBER Conference on Changes in the Structure of Wages, Cambridge, MA, August. National Bureau of Economic Research Working Paper no. 3358.

Ehrenberg, Ronald G. and Robert S. Smith. (1991) Modern Labor Economics: Theory and Public Policy. New York: Harper Collins.

Goldsmith, Selma F. (1967) "Changes in the Size Distribution of Income." In E. C. Budd, Inequality and Poverty. New York: Harper and Row.

Juhn, Chinhui, Kevin M. Murphy, and Brooks Pierce. (1989) Wage Inequality and the Rise in Returns to Skilt." Unpublished manuscript dated November 13, 1989.

Katz, Lawrence and Kevin M. Murphy. (1990) "Changes in Relative Wages, 1963-87: Supply and Demand Factors." Paper prepared for the NBER Conference on Changes in the Structure of Wages, Cambridge, MA, August.

Katz, Lawrence, and Ana L. Revenga. (1989) "Changes in the Structure of Wages: The United States vs Japan," Joumal of the Japanese and International Economies 3: 522-53.

Keat, Paul. (1960) "Long-Run Changes in Occupational Wage Structure, 1900-1956." Journal of Political Economy 73 (December): 584-600.

Kuznets, Simon. (1953) Shares of Upper Income Groups in Income and Savings. New York: National Bureau of Economic Research.

Miller, Herman P. (1955) income of the American People. A Volume in the Census Monograph Series. New York: John Wiley and Sons. 
Miller, Herman P. (1958) "Changes in the Industrial Distribution of Wages in the United States, 19391949:" In An Appraisal of the 1950 Census Income Data. Studies in Income and Wealth. Vol. 23 Princeton: Princeton University Press.

Miller, Herman P. (1966) Income Distribution in the United States. Washington, D.C.: G.P.O.

Ober, Harry. (1948) "Occupational Wage Differentials, 1907-1947." Monthly Labor Review (August): 12734.

Rockoff, Hugh. (1984) Drastic Measures: A History of Wage and Price Controls in the United States. New York: Cambridge University Press.

Thurow, Lester. (1975) Generating Inequality: Mechanisms of Distribution in the U.S. Economy. New York: Basic Books.

U.S. Bureau of the Census. (1943a) Sixteenth Census of the United States: 1940. Population, Vol. III. The Labor Force. Washington, D.C.: G.P.O.

(1943b) Sixteenth Census of the United States: 1940. Population. Vol. IV. Characteristics by Age. Part I: United States Summary. Washington, D.C.: G.P.O.

Summary. Washington, D.C.: G.P.O.

(1955) U.S. Census of Population: 1950. Vol. IV. Special Reports, Part I, Chapter D, Industrial Characteristics. Washington, D.C.: G.P.O.

(1964) Census of Population: 1960. Vol. I. Characteristics of the Population. Part I: United States Summary. Washington, D.C.: G.P.O.

D.C.: G.P.O.

(1967) U.S. Census of Population: 1960. Subject Reponts. Industrial Characteristics. Washington,

(1973) Census of Population: 1970. Subject Reports, Final Report PC(2)-7B. Industrial Characteristics. Washington, D.C.: G.P.O.

(1975) Historical Statistics of the United States. Washington, D.C.: G.P.O.

(1984) 1980 Census of Population. Vol. 1. Characteristics of the Population. Chapter D. Detailed Population Characteristics. Part 1. United States Summary. Section A. Washington, D.C.: G.P.O.

U.S. Bureau of Education. (1901) Report of the Commissioner of Education for the Year 1899-1900. Vol. 1. Washington, D.C.: G.P.O.

U.S. Department of Health, Education, and Welfare. (1954) Biennial Survey of Education in the United States, 1948-50. Washington, D.C.: G.P.O.

U.S. Department of the Interior. (1932) Biennial Survev of Education, 1928-1930. Vol. 2. Washington, D.C.: G.P.O.

U.S. Department of Labor. (1928 to 1945) Monthly Labor Review. "Office Workers' Earnings in New York State," and "Earnings of Office Workers in New York State Factories." 
U.S. Department of Labor. (1938 to 1952) Monthly Labor Review. Various titles concerning earnings In, wages of, and hours of the following industries: chemicals, clgars, cotton textlles, dyeing and finishing of cloth, fertilizer, foundries, grain-mlll products, iron and steel, lumber, men's neckwear, sawmills, shipyards, soap, steel, and woolen and worsted mills.

U.S. Department of Labor. (1944) -Trends in Earnings Among White Collar Workers During the War." Monthly Labor Review (May): 1033-48.

U.S. Department of Labor. (1949) The Termination Repon of the National War Labor Board: Industrial Disputes and Wage Stabilization in Wartime. Vol. 1. Washington, D.C.: G.P.O.

U.S. Interstate Commerce Commission. (1922 to 1952) Wage Statistics of Class I Steam Railways in the United States.

Weinstein, Michael M. (1980) Recoveny and Redistribution under the NIRA. Amsterdam: North-Holland.

Williamson, Jeffrey, and Peter H. Lindert. (1980) American Inequality: A Macroeconomic History. New York: Academlc Press.

Wool, Harold and Lester M. Pearlman. (1947) "Recent Occupational Trends," Monthly Labor Review (August): 139-47. 
Table 1: Summary Measures of the Wage Structure, 1940 to 1985

(1)

White Men Log of Weekly Wages 90-10 90-50 50-10

1940

1950

1960

$1960 a$

1985

1940

1950

1960

$\begin{array}{lll}1.414 & 0.674 & 0.740 \\ 1.060 & 0.472 & 0.588 \\ 1.211 & 0.521 & 0.690\end{array}$

$\begin{array}{lll}1.414 & 0.674 & 0.740 \\ 1.060 & 0.472 & 0.588 \\ 1.211 & 0.521 & 0.690\end{array}$

1.211
(2)

All Men Log of Weekly Wages 90-10 90-50 50-10

$\begin{array}{lll}1.447 & 0.654 & 0.793\end{array}$

$\begin{array}{lll}1.181 & 0.504 & 0.677\end{array}$

$\begin{array}{lll}1.250 & 0.567 & 0.723\end{array}$
(3)

Men > 21 years, $35+$ hours

Log of Weekly Wages

90-10

1.449

1,060

1.157

1.15

1.46

Variance of the Log of Weekly Wages

$\begin{array}{ll}0.313 & 0.325 \\ 0.241 & 0.259 \\ 0.262 & 0.275\end{array}$

Notes: Unless otherwise noted, the sample includes white males, 18 to 64 years old who were wage and salary earners working more than 39 weeks and earning more than one-half the minimum wage on a fulltime basis. $90-10$ is the average log(weekly wage) at the 90th percentile minus the average log(weekly wage) at the 10th percentile. Similar definitions hold for the group above the median (90-50) and below $(50-10)$. Column (3) is defined for comparability with Juhn, Murphy, and Pierce (1989). Figure I graphs column (3).

Sources: 1940, 1950, and 1960 PUMS. The 1960a and 1985 data are from Juhn, Murphy, and Pierce (table 1, 1989). 
Table 2: Ratios of Weekly Wages for Educational Groups by Experience

College/H.S. graduate

$\begin{array}{lrrrrr}\text { Experience Group } & 1940 & 1950 & 1960 & 1963 & 1987 \\ 1-5 \text { years } & & & & & \\ 6-10 & 1.742 & 1.357 & 1.528 & 1.538 & 1.880 \\ 11-15 & 1.728 & 1.369 & 1.522 & 1.397 & 1.704 \\ 16-20 & 1.777 & 1.462 & 1.565 & 1.584 & 1.635 \\ 21-25 & 1.657 & 1.421 & 1.602 & 1.462 & 1.689 \\ 26-30 & 1.408 & 1.449 & 1.627 & 1.516 & 1.722 \\ 31-35 & 1.475 & 1.466 & 1.580 & 1.467 & 1.661 \\ 36-40 & 1.393 & 1.367 & 1.641 & 1.390 & 1.533 \\ & 1.357 & 1.189 & 1.398 & 1.682 & 1.568\end{array}$

Some college/H.S. graduate

Experience Group

19401950

1960

1-5 years

1.195

1.029

1.128

6-10

1.164

1.151

1.198

1.219

1.147

$16-20$

1.320

1.215

1.270

1.218

1.164

1.276

1.192

1.126

1.063

1.215

26-30

0.989

1.084

1.280

$36-40$

0.999

1.204

1.118

H.S. graduate/8th grade

Experience Group

$\begin{array}{llll}1-5 \text { years } & 1.376 & 1.442 & 1.222 \\ 6-10 & 1.463 & 1.322 & 1.403 \\ 11-15 & 1.377 & 1.299 & 1.326 \\ 16-20 & 1.381 & 1.267 & 1.351 \\ 21-25 & 1.371 & 1.221 & 1.332 \\ 26-30 & 1.427 & 1.286 & 1.280 \\ 31-35 & 1.354 & 1.250 & 1.243 \\ 36-40 & 1.283 & 1.326 & 1.352\end{array}$

Notes: The sample includes white males, 18 to 64 years old who were wage and salary earners working more than 39 weeks and earning more than one-haff the minimum wage on a full-time basis. Experience $=$ (age -years of schooling - 6). High school graduates stop their education after graduation, as do those with only 8th grade or some college. The numbers for all experience groups in each year have not been given because they are misleading for periods of substantial educational increase. In 1940, for example, the overall ratio of weekly earnings among high school-only graduates to those who left after the eighth grade is 1.081 , a number substantially below any of the experience group averages. The reason is that high school graduates were much younger than those who left atter primary school, and the overall average aggregates across age or experience groups.

Sources: 1940, 1950, 1960 PUMS. Data for 1963 and 1987 are from the March Current Population Surveys and were provided by Lawrence Katz. 
Table 3: Weekly Wages Relative to All Non-Farm Weekly Wages by Selected Occupations

$\begin{array}{lrrr} & 1940 & 1950 & 1960 \\ \text { White collar } & 1.256 & 1.192 & 1.192 \\ \text { Blue collar } & 0.860 & 0.902 & 0.876 \\ & & & \\ \text { Professional } & 1.474 & 1.270 & 1.222 \\ \text { Clerical } & 0.988 & 0.952 & 0.878 \\ \text { Craft } & 1.039 & 1.037 & 0.979 \\ \text { Operative } & 0.856 & 0.872 & 0.828 \\ \text { Laborer } & 0.630 & 0.761 & 0.736 \\ \text { Service } & 0.737 & 0.789 & 0.735\end{array}$

Notes: The sample includes white males, 18 to 64 years old who were wage and salary earners working more than 39 weeks and earning more than one-half the minimum wage on a full-time basis. White collar inciudes professional, semiprofessional (in 1940), managerial, clerical, and sales workers. Blue collar includes craft, operative, laborer, and service workers.

Sources: 1940, 1950, and 1960 PUMS. 
Table 4: Interdecile Ranges of the Log of Weekly Earnings by Educational, Experience, and Occupational Groups

\section{Log Wage at the Soxh Percentlie - Log Wage at the 10th Percentile}

Pant A: Educational Group

\begin{tabular}{|c|c|c|c|c|c|}
\hline $\begin{array}{l}\text { Educational } \\
\text { Group }\end{array}$ & 1940 & 1950 & 1960 & $\begin{array}{l}\text { Difference } \\
1950-1940\end{array}$ & $\begin{array}{l}\text { Difference } \\
1960-1950\end{array}$ \\
\hline$<8$ years & 1.347 & 1.211 & 1.166 & -0.136 & -0.045 \\
\hline B & 1.378 & 0.988 & 1.034 & -0.390 & 0.046 \\
\hline $9-11$ & 1.369 & 0.976 & 1.073 & -0.393 & 0.097 \\
\hline 12 & 1.312 & 0.952 & 1.136 & -0.361 & 0.184 \\
\hline $13-15$ & 1.460 & 1.146 & 1.263 & -0.314 & 0.117 \\
\hline$>15$ & 1.540 & 1.207 & 1.312 & -0.333 & 0.105 \\
\hline
\end{tabular}

Part B: Experience Group

\begin{tabular}{|c|c|c|c|c|c|}
\hline & 1940 & 1950 & 1960 & $\begin{array}{l}\text { Difference } \\
1950-1940\end{array}$ & $\begin{array}{l}\text { Difference } \\
1960-1950\end{array}$ \\
\hline \multicolumn{6}{|l|}{$\begin{array}{l}\text { Experience } \\
\text { Group }\end{array}$} \\
\hline $1-5$ years & 1.253 & 1.246 & 1.429 & -0.007 & 0.183 \\
\hline $6-10$ & 1.347 & 1.032 & 1.177 & -0.315 & 0.145 \\
\hline $11-15$ & 1.347 & 1.004 & 1.088 & -0.343 & 0.083 \\
\hline $16-20$ & 1.426 & 0.921 & 1.067 & -0.504 & 0.146 \\
\hline $21-25$ & 1.291 & 0.978 & 1.058 & -0.313 & 0.080 \\
\hline $26-30$ & 1.427 & 0.996 & 1.088 & -0.431 & 0.092 \\
\hline $31-35$ & 1.416 & 1.019 & 1.109 & -0.398 & 0.091 \\
\hline $36-40$ & 1.455 & 1.041 & 1.109 & -0.414 & 0.068 \\
\hline
\end{tabular}

Part C: Occupational Group

\begin{tabular}{llllll} 
& White & \multicolumn{5}{c}{ Bluecollar } \\
\cline { 3 - 6 } Collar & Craft & Operative & Laborer & All \\
1940 & & & & & \\
1950 & 1.465 & 1.105 & 1.090 & 1.138 & 1.236 \\
1960 & 1.146 & 0.856 & 0.881 & 1.059 & 1.017 \\
& 1.238 & 0.913 & 0.979 & 1.028 & 0.889
\end{tabular}

Notes: The sample includes white males, 18 to 64 years old who were wage and salary earners working more than 39 weeks and earning more than one-hall the minimum wage on a full-time basis. White coilar includes protessionals, semiprofessionals (in 1940), managers, and clerical and sales workers. Blue coliar includes craft, operative, laborer, and service workers.

Sources: 1940, 1950, and 1960 PUMS. 
Table 5: Interdecile Ranges of the Log of Weekly Earnings by Educational Attainment within Region

Educational

Log Wage at the goth Percentile - Log Wage at the 10th Percentile

Group

\begin{tabular}{|c|c|c|c|c|c|}
\hline & & & & & \\
\hline & 1940 & 1950 & 1960 & $\begin{array}{l}\text { Difference } \\
1950-1940\end{array}$ & $\begin{array}{l}\text { Difference } \\
1960-1950\end{array}$ \\
\hline$<8$ years & 1.446 & 1.273 & 1.185 & -0.173 & -0.088 \\
\hline 8 & 1.478 & 1.159 & 1.181 & -0.319 & 0.022 \\
\hline $9-11$ & 1.463 & 1.116 & 1.189 & -0.347 & 0.073 \\
\hline 12 & 1.407 & 1.058 & 1.288 & -0.349 & 0.230 \\
\hline $13-15$ & 1.466 & 1.229 & 1.331 & -0.237 & 0.102 \\
\hline 15 & 1.552 & 1.317 & 1.291 & -0.235 & -0.026 \\
\hline
\end{tabular}

\begin{tabular}{lrrrrr} 
& \multicolumn{2}{c}{ Northeast } \\
& 1940 & 1950 & 1960 & $\begin{array}{l}\text { Difference } \\
1950-1940\end{array}$ & $\begin{array}{l}\text { Difference } \\
1960-1950\end{array}$ \\
$<8$ years & & & & & \\
8 & 1.133 & 0.855 & 0.988 & -0.278 & 0.133 \\
$9-11$ & 1.193 & 0.797 & 0.880 & -0.396 & 0.083 \\
12 & 1.238 & 0.840 & 0.920 & -0.398 & 0.080 \\
$13-15$ & 1.233 & 0.902 & 0.995 & -0.331 & 0.093 \\
$>15$ & 1.531 & 1.162 & 1.118 & -0.369 & -0.044 \\
& 1.532 & 1.148 & 1.304 & -0.384 & 0.156
\end{tabular}

Note: The sample includes white males, 18 to 64 years old who were wage and salary earners working more than 39 weeks and earning more than one-half the minimum wage on a full-time basis.

Sources: 1940, 1950, and 1950 PUMS. 
Table 6: Change in the Residual from a Wage Equation by Percentile

$\begin{array}{ccc}\text { Percentile } & \begin{array}{c}\text { Difference in } \\ \text { the Residual } \\ 1950-1940\end{array} & \begin{array}{c}\text { Difference in } \\ \text { the Residual } \\ 1960-1950\end{array} \\ 1 & -0.250 & 0.208 \\ 5 & 0.069 & 0.020 \\ 10 & 0.122 & -0.032 \\ 25 & 0.073 & -0.027 \\ 50 & -0.002 & -0.003 \\ 75 & -0.056 & 0.007 \\ 90 & -0.088 & 0.016 \\ 95 & -0.090 & 0.008 \\ 99 & 0.060 & -0.052\end{array}$

Notes: The sample includes white males, 18 to 64 years old who were wage and salary earners working more than 39 weeks and earning more than one-haff the minimum wage on a full-time basis. The residuals are derived from wage equations that regress on the log of weekly wages: experience (= age years of school - 6), experience squared, years of school, schooling squared, the interaction of experience and schooling, regional dummies, marital status dummies, head of household dummy, veteran status (for 1950 and 1960), and city or urban or SMSA area.

Sources: 1940, 1950, and 1960 PUMS. 
Table 7: Decomposition of the Change in the Wage Structure, 1940 to 1950

Using 1950 as the Base Year

\begin{tabular}{lcccc} 
& & \multicolumn{3}{c}{ Due techanges in } \\
\cline { 3 - 5 } $\begin{array}{l}\text { Difference in } \\
\text { Percentiles }\end{array}$ & $\begin{array}{l}\text { Total Change } \\
\text { Log(wages) }\end{array}$ & $\begin{array}{l}\text { Observed } \\
\text { Quantities }\end{array}$ & $\begin{array}{l}\text { Observed } \\
\text { Prices }\end{array}$ & $\begin{array}{l}\text { Distribution } \\
\text { of Residuals }\end{array}$ \\
$90-10$ & & -0.172 & -0.167 & -0.016 \\
$90-50$ & -0.354 & -0.088 & -0.077 & -0.036 \\
$50-10$ & -0.202 & -0.083 & -0.090 & +0.020
\end{tabular}

Using 1940 as the Base Year

\begin{tabular}{lcccc}
\cline { 3 - 5 } $\begin{array}{l}\text { Difference in } \\
\text { Percentiles }\end{array}$ & $\begin{array}{c}\text { Total Change } \\
\text { Log(wages) }\end{array}$ & $\begin{array}{l}\text { Observed } \\
\text { Quantities }\end{array}$ & $\begin{array}{l}\text { Obserechange in } \\
\text { Prices }\end{array}$ & $\begin{array}{l}\text { Distribution } \\
\text { of Residuals }\end{array}$ \\
$90-10$ & & & & \\
$90-50$ & -0.354 & +0.007 & -0.143 & -0.219 \\
$50-10$ & -0.202 & -0.014 & -0.074 & -0.114 \\
& -0.153 & +0.021 & -0.069 & -0.105
\end{tabular}

- Total change for the 90-10 row, for example, is the (log wage at the 9oth percentile - log wage at the 10 th percentile $)_{1950}$ - $\left(\log\right.$ wage at the 9oth percentile - $\log$ wage at the 10 th percentile) ${ }_{120}$

Notes: The decomposition is described in the text. The wage equation (1) was estimated for 1940 and 1950 on the sample of white male wage and salary earners, 18 to 64 years old, whose (full-time) weekly wage and salary earnings were more than one-half the current minimum wage. The variables included are: experience (= age - years of school - 6), experience squared, years of school, schooling squared, an interaction of schooling and experience, dummy variables for high school and college graduation, for region, for urban residence, for marital status, for household headship, and for foreign birth.

Sources: 1940, 1950, and 1960 PUMS. See text for a description of the decomposition procedure. 
Table 8: Pay Ratios of Skilled to Unskilled Workers, 1907-1960

\begin{tabular}{|c|c|c|c|c|c|c|c|}
\hline & $\begin{array}{l}\text { (1) } \\
\text { NICB } \\
\text { (hourly) }\end{array}$ & $\begin{array}{l}\text { (2) } \\
\text { W\&L } \\
\text { Index }\end{array}$ & $\begin{array}{l}\text { (3) } \\
\text { Ober \& Miller } \\
{[\text { BLS] }}\end{array}$ & \multicolumn{2}{|c|}{$\begin{array}{l}\text { (4) } \\
\text { Railroad Clerks/ } \\
\text { Laborers } \\
\text { (monthly) (hourly) }\end{array}$} & $\begin{array}{l}\quad \text { (5) } \\
\text { Railroad } \\
\text { Machinists/ } \\
\text { Laborers }\end{array}$ & $\begin{array}{l}\text { (6) } \\
\text { NYS Clerks/ } \\
\text { Unskilled } \\
\text { (weekly) }\end{array}$ \\
\hline $\begin{array}{l}1907 \\
1909\end{array}$ & & $\begin{array}{l}1.849 \\
1.909\end{array}$ & 2.05 & & & & \\
\hline 1917 & & 1.876 & & & & & \\
\hline 1918 & & 1.722 & 1.75 & & & & \\
\hline 1922 & 1.408 & 1.943 & & 1.57 & 1.57 & 2.03 & \\
\hline 1923 & 1.397 & & & 1.53 & 1.57 & 1.95 & 1.89 \\
\hline 1924 & 1.406 & & & 1.58 & 1.58 & 1.92 & 1.95 \\
\hline 1925 & 1.415 & 1.952 & & 1.60 & 1.59 & 1.94 & 1.94 \\
\hline 1926 & 1.414 & & & 1.60 & 1.60 & 1.95 & 1.96 \\
\hline 1927 & 1.393 & & & 1.64 & 1.63 & 1.97 & 1.99 \\
\hline 1928 & 1.390 & & & 1.69 & 1.68 & 1.96 & 1.96 \\
\hline 1929 & 1.374 & & & 1.69 & 1.68 & 2.04 & 1.98 \\
\hline 1930 & 1.387 & 1.922 & & 1.79 & 1.71 & 2.06 & 2.25 \\
\hline 1931 & 1.378 & & 1.80 & 1.93 & 1.74 & 2.06 & 2.41 \\
\hline 1932 & 1.398 & & & 2.14 & 1.77 & 2.06 & 2.91 \\
\hline 1933 & 1.372 & & & 2.06 & 1.81 & 2.09 & 2.78 \\
\hline 1934 & 1.342 & & & 1.98 & 1.81 & 2.08 & 2.60 \\
\hline 1935 & 1.343 & 1.880 & & 1.97 & 1.82 & 2.10 & 2.30 \\
\hline 1936 & 1.375 & & & 1.85 & 1.79 & 2.09 & 2.13 \\
\hline 1937 & 1.363 & & & 1.81 & 1.75 & 2.03 & 2.00 \\
\hline 1938 & 1.369 & & 1.65 & 1.81 & 1.72 & 1.95 & 2.11 \\
\hline 1939 & 1,360 & 1.888 & & 1.75 & 1.71 & 1.95 & 2.01 \\
\hline 1940 & 1.354 & & & 1.73 & 1.70 & 1.95 & 1.89 \\
\hline 1941 & 1.340 & & & 1.65 & 1.63 & 1.89 & 1.77 \\
\hline 1942 & 1.349 & & & 1.57 & 1.54 & 1.81 & 1.68 \\
\hline 1943 & 1.363 & & & 1.44 & 1.43 & 1.69 & 1.49 \\
\hline 1944 & 1.376 & & & 1.39 & 1.42 & 1.70 & \\
\hline 1945 & 1.361 & & & 1.39 & 1.41 & 1.70 & \\
\hline 1946 & 1.300 & & 1.55 & 1.38 & 1.35 & 1.55 & \\
\hline 1947 & 1.289 & & & 1.35 & 1.33 & 1.52 & \\
\hline 1948 & 1.277 & 1.773 & & 1.31 & 1.29 & 1.46 & \\
\hline 1949 & & & & 1.32 & 1.28 & 1.42 & \\
\hline 1950 & & & [1.580] & 1.34 & 1.27 & 1.41 & \\
\hline 1951 & & & & 1.32 & 1.25 & 1.37 & \\
\hline 1952 & & & 1.37 & 1,31 & 1.23 & 1.34 & \\
\hline 1960 & & & [1.603] & & & & \\
\hline
\end{tabular}


Notes: The Williamson and Lindert (W\&L) index, column (2), splices together several ratios of skilled to unskilled wages. Primary among these is that from the National Industrial Conference Board (NICB), also given here in column (1) for 1922 to 1948 . The column (1) NICB data are the ratio of the hourly wages of skilled and semiskilled manufacturing production workers to those for unskilled manufacturing production workers. Note that the Williamson and Lindert numbers are an index, and thus do not give the actual percentages by which skilled workers earned more than the unskilled. The BLS series is the ratio of the hourly wage rate for mechanics, electricians, and carpenters in six cities to that for janitors and custodians. The dates for the BLS series are: 1950/51 and 1960/61. The Ober-Miller series is the ratio of hourly wages of skilled labor to that for unskilled labor in various manufacturing industries in urban areas. The dates for the Ober-Miller series are: 1907, 1918/19, 1931/32, 1937/40, 1945/47, and 1952/53. The railroad data are for clerks, machinists, and laborers working on Class-I Steam Railroads. For the hourly earnings, total compensation was divided by the total number of hours worked; for the monthly earnings, total compensation was divided by the average number of workers in the middle of month, which in turn was divided by 12 . The New York State clerical data are the weekly wages of male clerks working in New York State factories. The denominator is the unskilled NICB series for weekly wages.

Sources: U.S. Bureau of the Census (1975), series D-839 and D-842 for column (1). Williamson and Lindert (1980, p. 307-8) for columns (2) and (3). Column (2) is their series (5); column (3) is their series (6) and (7), for the BLS. U.S. Interstate Commerce Commission (1922 to 1952) for columns (4) and (5). U.S. Bureau of the Census (1975) series D-841 and Monthly Labor Review (1928 to 1945) for column (6). An Appendix to this paper, "Skill Ratios and Wage Distributions: 1920's to 1950's," details the sources and the underlying series of columns (4), (5), and (6). 


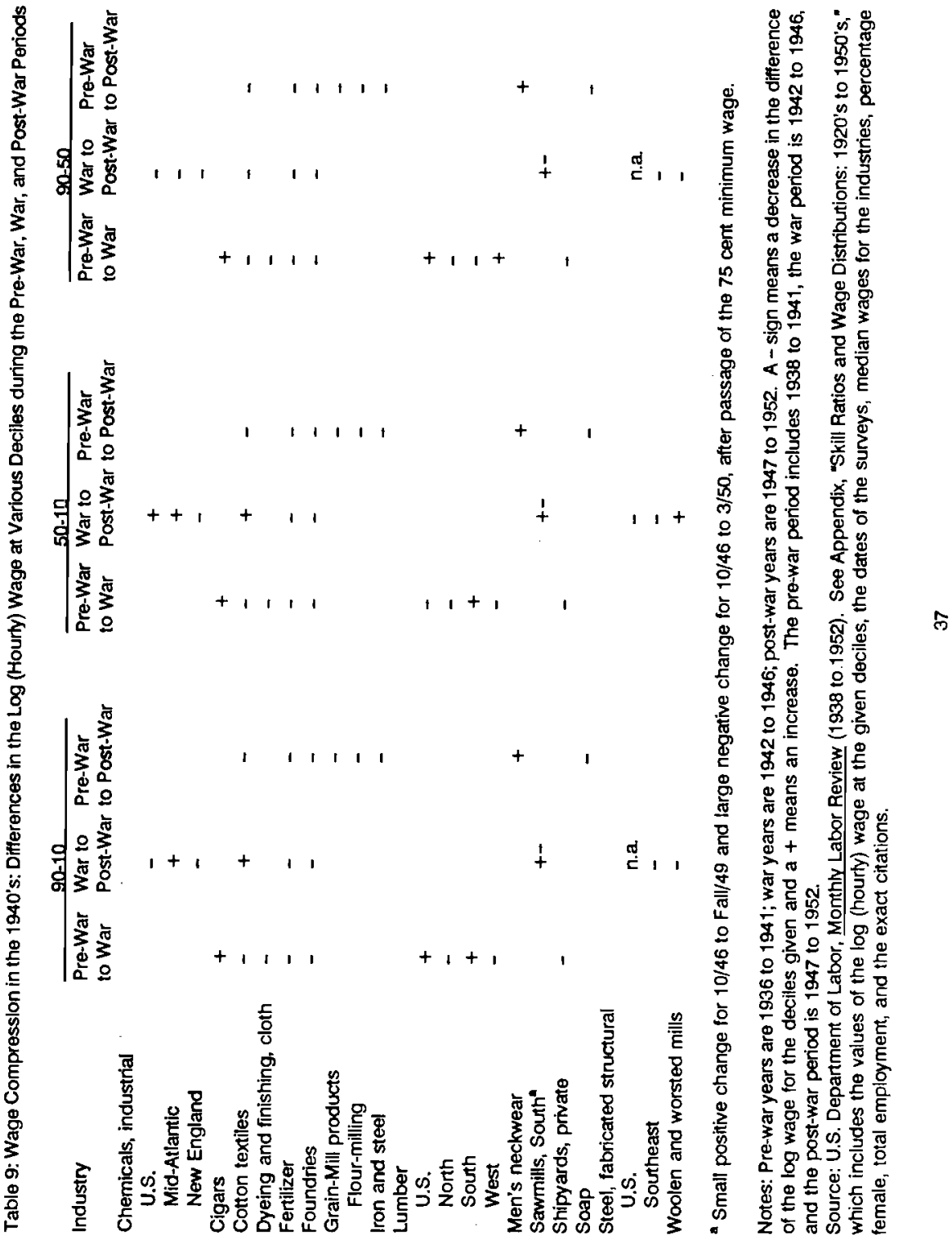


Table 10: The Demand for Educated Labor: 1940 to 1980

Average Annual Percentage Change

in the Demand for White Males with

Decade

Fewer than 13 years

of schooling

1940 's

1950 's

1960 's

1970's
$2.02 \%$

1.13

1.16

1.61
More than 12 years

of schooling

$2.06 \%$

2.18

1.82

Notes: A demand index in year $t$ for schooling level $j\left(D_{p}\right)$ is constructed as a weighted average of the proportion of the white, male labor force who attained a particular level of schooling (i) by industry (i) in 1960. The weights $\left(\rho_{h}\right)$, which change with time, are the employment shares in year $t$ by industriai sector i. Thus, for each level of schooling $(j)$ and time period $(t): D_{i}=\Sigma_{i} p_{n} \cdot s_{i j}{ }^{60}$. The (white male) labor force in year $t$ of schooling level $\}$, given the 1960 schooling weights, would be: $L_{4} D_{k}$. The numbers given are the average annualized percentage change of this number.

Sources: U.S. Bureau of the Census (1943a, 1955, 1967, 1973, 1984). 
Table 11: Distribution of Educational Attainment, 1940-1960: White Males, 25 to 64 years

\begin{tabular}{lcccccc} 
& \multicolumn{5}{c}{ Years of Schooling } & \\
1940 & $<8$ & 8 & $9-11$ & 12 & $13-15$ & $16+$ \\
$25-34$ & $17.7 \%$ & $23.8 \%$ & $22.4 \%$ & $21.2 \%$ & $7.1 \%$ & $7.8 \%$ \\
$35-44$ & 25.9 & 31.5 & 17.4 & 12.9 & 5.8 & 6.5 \\
$45-54$ & 35.1 & 33.3 & 12.2 & 9.8 & 4.6 & 5.0 \\
$55-64$ & 40.6 & 34.2 & 9.1 & 8.1 & 3.7 & 4.3 \\
& & & & & & \\
$25-64$ & 26.0 & 30.0 & 16.3 & 14.0 & 5.6 & 6.1 \\
& & & & & & \\
1950 & & & & & & \\
$25-34$ & 13.0 & 13.4 & 22.0 & 30.9 & 10.7 & 10.0 \\
$35-44$ & 19.3 & 20.8 & 21.1 & 21.6 & 8.1 & 9.1 \\
$45-54$ & 28.4 & 27.6 & 16.3 & 14.5 & 6.0 & 7.2 \\
$55-64$ & 38.1 & 28.4 & 12.2 & 10.7 & 4.9 & 5.7 \\
& & & & & & \\
$25-64$ & 22.9 & 21.4 & 18.7 & 20.9 & 7.8 & 8.3 \\
& & & & & & \\
1960 & & & & & & \\
$25-34$ & 9.9 & 9.7 & 21.1 & 31.2 & 12.3 & 15.8 \\
$35-44$ & 12.4 & 13.1 & 21.4 & 30.3 & 10.3 & 12.5 \\
$45-54$ & 18.5 & 20.8 & 21.1 & 20.6 & 8.6 & 10.4 \\
$55-64$ & 34.6 & 24.4 & 16.0 & 11.8 & 6.6 & 6.6 \\
$25-64$ & 18.0 & 16.3 & 20.2 & 24.5 & 9.7 & 11.3
\end{tabular}

Source: Calculated from data in U.S. Bureau of the Census (1943b, 1953, 1964). 
Figure 1

Difference in the Log Wage at the 90th and 10th Percentiles, 1940 to 1985

Log(Wage), 90th-10th

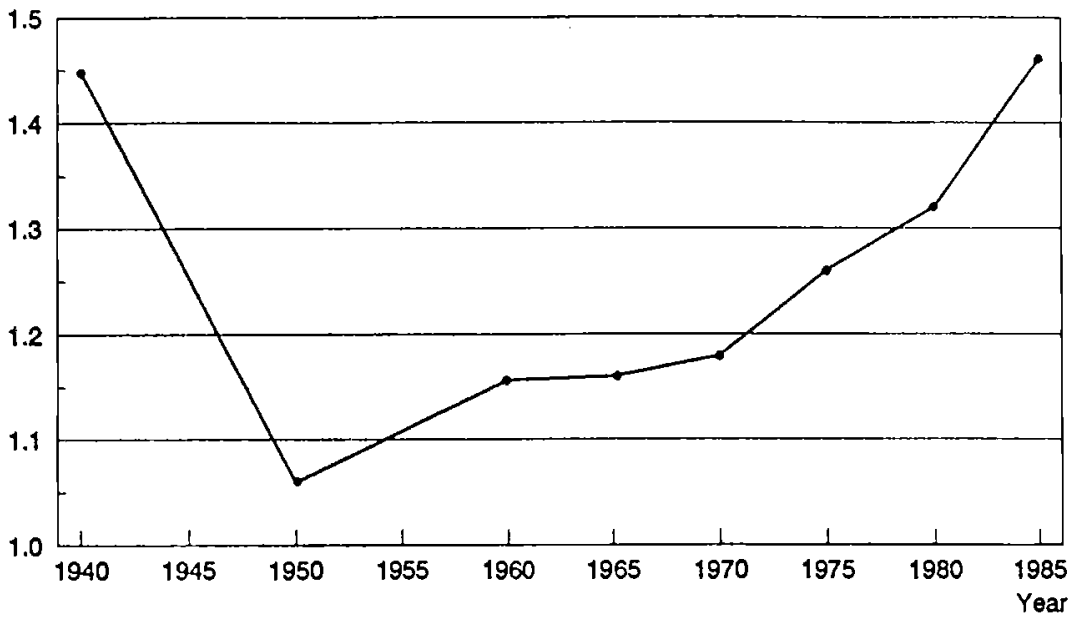

Source: Table 1. 
Figure It

Clerk Wages Relative to Unskilled and Laborer Wages, Males: 1922 to 1952

Ratio

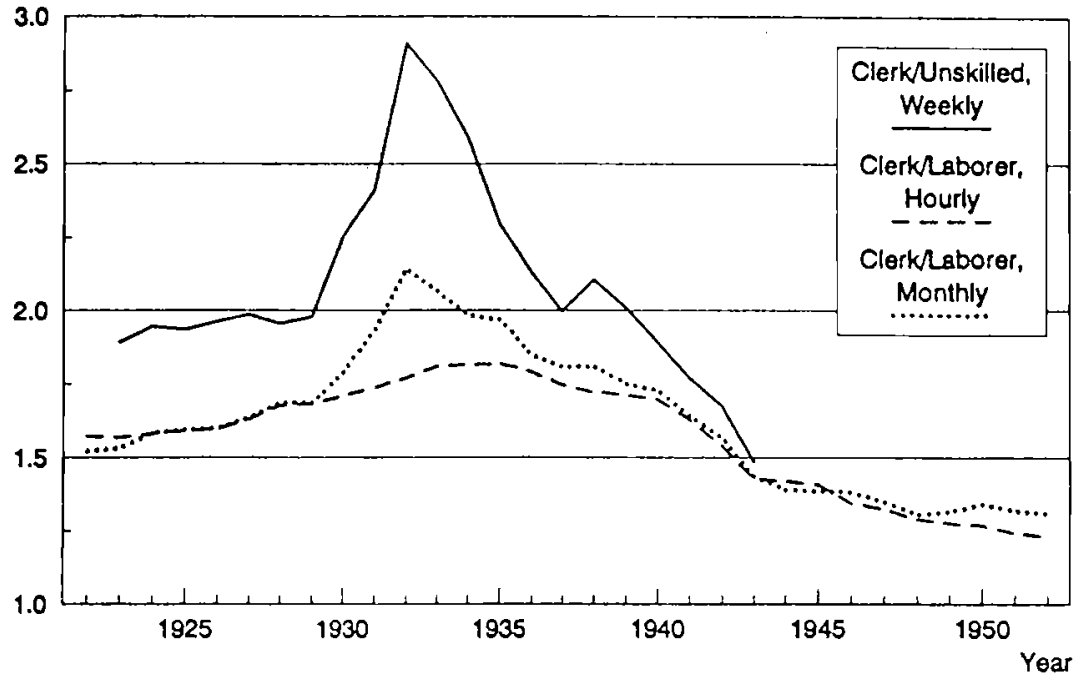

Source: Table 8, columns (4) and (6).

Notes: The weekly series for clerks is for male office workers in New York State factories, and the corresponding series for the unskilled refers to production workers in 25 industries (from National Industrial Conference Board data). The hourly and monthly series are for workers on class-l steam railroads. 
printed draft of $7 / 30 / 91$

\section{APPENDIX \\ Skll Ratios and Wage Distributions:}

1920's to 1950's

To Accompany:

Claudia Goldin and Robert Margo

The Great Compression:

The Wage Structure in the United States at Mid-Century" 
This appendix details two data compilations relating to the wage structure from the 1920's to the 1950's. In the first we construct several wage series for white-collar workers to explore skill differentials before and during the Great Depression. In the second we explore how the wage distribution changed during the 1940's - from the pre-war, to the wartime, to the post-war periods.

\section{Skill Ratios, 1922 to 1952}

Because 1930's depression unemployment was disproportionately experienced by the unskilled and lesser educated, the wage structure in 1939 could have anomalous. Thus, the compression observed in the census data from 1939 to 1949 could have returned the wage structure to a previous equilibrium, perhaps that of the late 1920's. Existing data on the hourly wages of manufacturing workers indicates that there was little change in the ratio of the skilled to the unskilled during the 1930's. But these data are a misleading indicator of the skill premium during the 1930's. Not only do they exclude most of the educated population who were not production workers in manufacturing, but they include skilled and unskilled operatives in large firms only. Further, the manufacturing-operative data tell us little about the fate of white-collar workers relative to production workers, and it is the premium to education that has been our primary concern here.

No white-collar wage series currently exist for the twentieth century that cover privatesector workers, not self-employed. Available series are not entirely useful for a number of reasons. They either cover public-sector employees (e.g., teachers), include only the selfemployed for whom hours and days of work are not given (e.g., physicians, laywers), or are limited in duration (e.g., engineers). To remedy omissions in the data, we have assembled two new series for clerical workers and have compared our series with those for manufacturing workers generally or unskilled workers in the same industry. The two series are clerical workers in New York State factories and clerks hired by class-l steam railroads.

The first comes from surveys of office personnel working in New York State factories. The 
data wore collected by the New York State Department of Labor, published In The Industrial Bulletin (Albany, New York), and then reprinted, in their exact form, in the Monthly Labor Review. For all years but 1923, the data can be found in the Monthly Labor Review. The wage statistics were broken down by sex and by whether the factory was located In upstate New York or in New York City. We have compiled them by sex only. The wages are weekly rates and there is no evidence contained on hours of work. To construct skill ratios, we have divided the office worker weekly wages by weekly wages of unskilled workers (for males) and operatives (for females) contained in the National Industrial Conference Board series from U.S. Bureau of the Census (1975, see also Beney, 1936).

The second data set is more comprehensive and is from Wage Statistics of Class I Steam Railways in the United States (U.S. Interstate Commerce Commission, 1922 to 1952). We define clerks as Clerks ( $A, B$, and C) in Reporting Division Ii: Professional, Clerical, and General. Laborers are Common Laborers (or the two categories of General Laborers after 1934) in Reporting Division IV: Maintenance of Equipment and Stores. Machinists are also in Reporting Division IV and are a separate category. End of year summaries have been used in all cases. Monthly earnings are (total compensation)/(average number of employees, middle of month). Hourly earnings are (totai compensation)/(total time paid for - time paid for but not worked). There is no breakdown by sex, and women may have been employed in some of the clerk positions, although it is likely that there were very few. Typists, stenographers, and secretaries composed a completely different group. The two skill ratios for the railroad data are the clerk series divided by the laborer series and the machinist series divided by the laborer series. There is both a monthly series and an hourly series spanning the 1922 to 1952 period.

All wages and skill ratios are presented in Tables $1 \mathrm{~A}$ and $2 \mathrm{~A}$. We graph the three clerks ratios in Figure IA. We Initially constructed these series to discover whether 1939 was an anomalous year in the history of the wage structure, and thus whether the compression that we observe from 1939 to 1949 merely reinstituted a previous equilibrium. The skill ratios are clear 
on this point. In all three cases the ratio of clerk to laborer wages in the late 1920's is approximately equal to its value in 1939. By 1939, the Great Depression no longer had an effect on the skill ratio.

But during the 1930's, skill ratios increased and then decreased. Looking first at the monthly (railroad) and weekly (NYS) series, the premium to skill rose substantially -- by 26 to 31 percent. Using the railroad data, it is clear that much of the rise was due to the collapse in the hours of the unskilled compared with the skilled. But even on an hourly basis, the skill differential decreased by about 8 percent. Another finding of interest is that the skill premium before 1929 did not decrease, but, rather, Increased slightly In alt series. Finally, the compression in wages that we find using aggregate census data between 1939 and 1949 is quite evident here as well. After returning to about the value it achieved in the late 1920's, the ratio began a steacty decline after 1940. Further, it continued to decline after war was declared, after the National War Labor Board gained power to stabilize wages, and after victory was declared and the command economy was dismantled.

Figure IIA contains all three railroad series. The machinist to laborer ratio was stable before the depression, then plummeted during and after World War II, similar to that for clerks. Although machinists lost fewer hours than did laborers duning the depression, the difference is small, particularly in comparison with the clerk to laborer series. (Note that that monthly series for machinists to laborers has not been drawn in Figure IIA but does appear in Figure IIIA.)

The importance of the machinist to laborer series is apparent in Figure IIIA, which includes the hourty and monthly series in addition to the frequently-used NICB series (see, e.g., Williamson and Lindert, 1980). The NICB series is for hourly workers and is the ratio of skilled and semiskilled manufacturing workers to unskilled manufacturing workers in large firms across 25 industries. Those who have tried to document changing skill differentials in the mid-twentieth century have found the NICB series frustrating. Williamson and Lindert (1980), in their chapter on twentieth century skill differentials, even substituted another datum for the 1948 NICB ratio. 
The problem is that the NICB ratio is not a series that reveals much about skill differentials either between the more educated and the less educated or between craftsmen and laborers. It is merely the ratio of more skilled operatives to less skilled operatives

Figure IVA contains the NYS clerk series for both males and females, where the female clerk weekly wage is divided by the lemale operative weekly wage from the NICB data. (Note that the female clerk series is not contained in Tables $1 \mathrm{~A}$ and $2 \mathrm{~A}$.) The two series are similar in shape and the difference is likely the result of the lower wages women in clerical positions received compared with men. Women's wages are generally more compressed than are men's wages, and thus female clerks do not receive much more than female operatives. Still, the male and female series move together, rising in the first years of the depression, then falling, so that the overall movement from 1929 to 1939 is trivial.

The findings from the two series support the comparisons we have made between 1939 and 1949. The wage structure of 1939 was not anomalous, at least not in comparison with data from the late 1920's. The ratio of hourly, weekly, and monthly earnings in clerical work to those for manufacturing workers or railroad laborers was virtually identical in the late 1920's and 1939. But the data also demonstrate that even though the two endpoints are similar, the 1930's did witness large shitts in the wage structure. The wage structure, as proxied by the ratio of the hourly clerical wage to that of a lesser skilled worker, rose slightly from the early 1920's to the onset of the depression. Just after 1929 it rose more rapidly and peaked in 1932 or 1933. The ratio then fell by the same speed and magnitude that had characterized its rise, attaining by 1939 the approximate level it had some ten years earlier. The increase and decrease for the weekly and monthly series are considerably larger, reflecting the substantial decrease and subsequent increase in hours of work experienced by lower-educated and less-skilled workers. The skill premium then continued its descent, to at least 1952. 
The Wage Distribution from 1938 to 1952

The wage structure was compressed in various ways during the 1940's, and a question naturally arises concerning the impact of World War II. The war must have increased the demand for less-skilled workers relative to skilled workers, but how did changed demands get translated into a changed structure of wages in an era of wage control? The National War Labor Board (NWLB) had to approve ail wage increases, save for those at the very low end of the scale. Another question, not answered by the decennial census figures, is whether the compression of the 1940's took place only during American involvement in World War II or whether it continued after V J Day. Aiso of importance is which portions of the wage distribution were compressed. If the NWLB had an impact, it was likely to have been experienced at the lower end of the distribution.

From the late 1930's to the early 1950's, the Bureau of Labor Statistics conducted more than 70 industry studies that contain detailed information on the wage structure. Many of these studies were conducted to provide evidence on the necessity for or the impact of the minimum wage. Only 15 industries contain studies on two of the three periods of interest - the pre-war period (from the late 1930's to 1941), the war period (from 1942 to 1946), and the post-war period (from 1947 to 1952). Our periodization allows time for the termination of the NWLB to run its course and for its initial estabilishment to take effect.

Three summary statistics of the wage distribution are used: the difference of the log (hourly wage) at the 9oth percentile and at the 10th percentile (90-10), the difference at the 50th and the 10th (50-10), and the difference at the 90th and the 50th (90-50). The last two reveal what is happening above and below the median, while the first reveals movements in the tails.

For most of the industries, the BLS surveyed exactly the same types of firms in each of the periods. In some cases it did not. In foundries, for example, five types were surveyed at different periods. But the wage structure did not vary much among the different labor forces, and a very clear picture of compression in the wage structure across the foundries emerges. In other 
cases, the national average disguised important change within various regions. This was particularly the case where ever the South loomed large in the employment of an industry, as in the case of lumber. The timing of increases to the minimum wage is of crucial importance in the South, where is was often binding on a large proportion of the labor force. Comparisons just before and after a change in the minimum wage can give a misleading sense of longer-term trends in the wage structure. There are other cases in which the upper and lower bounds of the wage distribution encompassed a group larger than the lowest 10th (or highest 10th) percentile, but for which certain regions (e.g., as in steel) could be used.

The results of these computations are in Table $3 A$, in which part $A$ includes the summary measures of the wage structure and part B contains further information about the industries. The results show a general wage compression from the pre-war to war periods both above and below the median. The exceptions are mainly female-intensive Industries. The NWLB could have affected the distribution above the median, but its main effects would have been felt at the very lowest end of the wage structure. Thus, firms managed to circumvent wage controls, atthough they may have found it difficult to raise wages at the highest end. Wage compression, however, did not end with the war. Rather, it continued from the war to post-war periods with about the same effect on the wage structure.

The BLS surveys reveal that the compression of the 1940's was not contained solely in the period of the war nor was it confined only to the lower tail of the wage distribution. Although the NWLB may have had an impact on the wage structure through its policies of ailowing substandard wages to rise, there appears to have been considerable movement around the median as well. 
Table 1A: Average Weekly Earnings and Skill Ratios: Male Clerical Workers, and Unskilled and Skilled Male Manufacturing Operatives

\begin{tabular}{llllll}
\multicolumn{5}{c}{ Average Weekly Earnings } \\
& $\begin{array}{l}\text { (1) } \\
\text { Male }\end{array}$ & $\begin{array}{l}\text { (2) } \\
\text { Male } \\
\text { Unskilled }\end{array}$ & $\begin{array}{l}\text { (3) } \\
\text { Male } \\
\text { Skilled }\end{array}$ & $\begin{array}{l}\text { (4) } \\
\text { Clerical/ } \\
\text { Unskilled } \\
(1) /(2)\end{array}$ & $\begin{array}{l}\text { (5) } \\
\text { Clerical/ } \\
\text { Skilled } \\
(1) /(3)\end{array}$ \\
& & & & & \\
1923 & 42.18 & 22.28 & 30.81 & 1.893 & 1.369 \\
1924 & 43.60 & 22.41 & 30.55 & 1.946 & 1.427 \\
1925 & 44.38 & 22.93 & 31.29 & 1.935 & 1.418 \\
1926 & 45.54 & 23.21 & 31.61 & 1.962 & 1.441 \\
1927 & 46.73 & 23.54 & 31.51 & 1.985 & 1.483 \\
1928 & 46.70 & 23.89 & 31.94 & 1.955 & 1.462 \\
1929 & 48.24 & 24.40 & 32.60 & 1.977 & 1.480 \\
1930 & 49.34 & 21.90 & 29.17 & 2.253 & 1.691 \\
1931 & 46.22 & 19.18 & 25.05 & 2.410 & 1.845 \\
1932 & 42.14 & 14.48 & 19.48 & 2.910 & 2.163 \\
1933 & 41.52 & 14.91 & 20.27 & 2.784 & 2.048 \\
1934 & 42.71 & 16.46 & 22.45 & 2.595 & 1.902 \\
1935 & 42.04 & 18.32 & 24.98 & 2.295 & 1.683 \\
1936 & 42.67 & 20.00 & 27.58 & 2.134 & 1.547 \\
1937 & 44.76 & 22.41 & 30.39 & 1.997 & 1.473 \\
1938 & 43.52 & 20.67 & 27.49 & 2.105 & 1.583 \\
1939 & 45.90 & 22.82 & 30.53 & 2.011 & 1.503 \\
1940 & 45.25 & 23.91 & 32.41 & 1.893 & 1.396 \\
1941 & 49.99 & 28.19 & 38.32 & 1.773 & 1.305 \\
1942 & 56.17 & 33.49 & 46.31 & 1.677 & 1.213 \\
1943 & 57.83 & 38.86 & 54.10 & 1.488 & 1.069
\end{tabular}

Notes and Sources:

Clerical Workers: For 1924 to 1929, "Office Workers' Earnings in New York State;" for data after 1928, "Earnings of Otfice Workers in New York State Factories, 1920 to 1929, October 1930, 1931, 1932, 1933, 1934, 1935, 1936, 1937, 1938, 1939, 1940, 1941, 1942, 1943," Monthly Labor Review, various issues. Only data that included a breakdown by sex could be used. The Monthly Labor Review data were reprinted from The Industrial Bulletin (Albany, N.Y.), and the issue for November 1925 provided the 1923 figure.

Male Unskilled and Skilled: U.S. Bureau of the Census (1975), senies D-841 and D-844. Both are for average weekly earnings among production workers in twenty-five manufacturing industries and come from the National Industrial Conference Board series. That for "skilled" workers is for skilled and emiskilled. 
Table 2A: Average Monthly Earnings, Average Hourly Earnings, Skill Ratios, and Average Hours for Male Clerks, Laborers, and Machinists on Class-l Steam Railroads

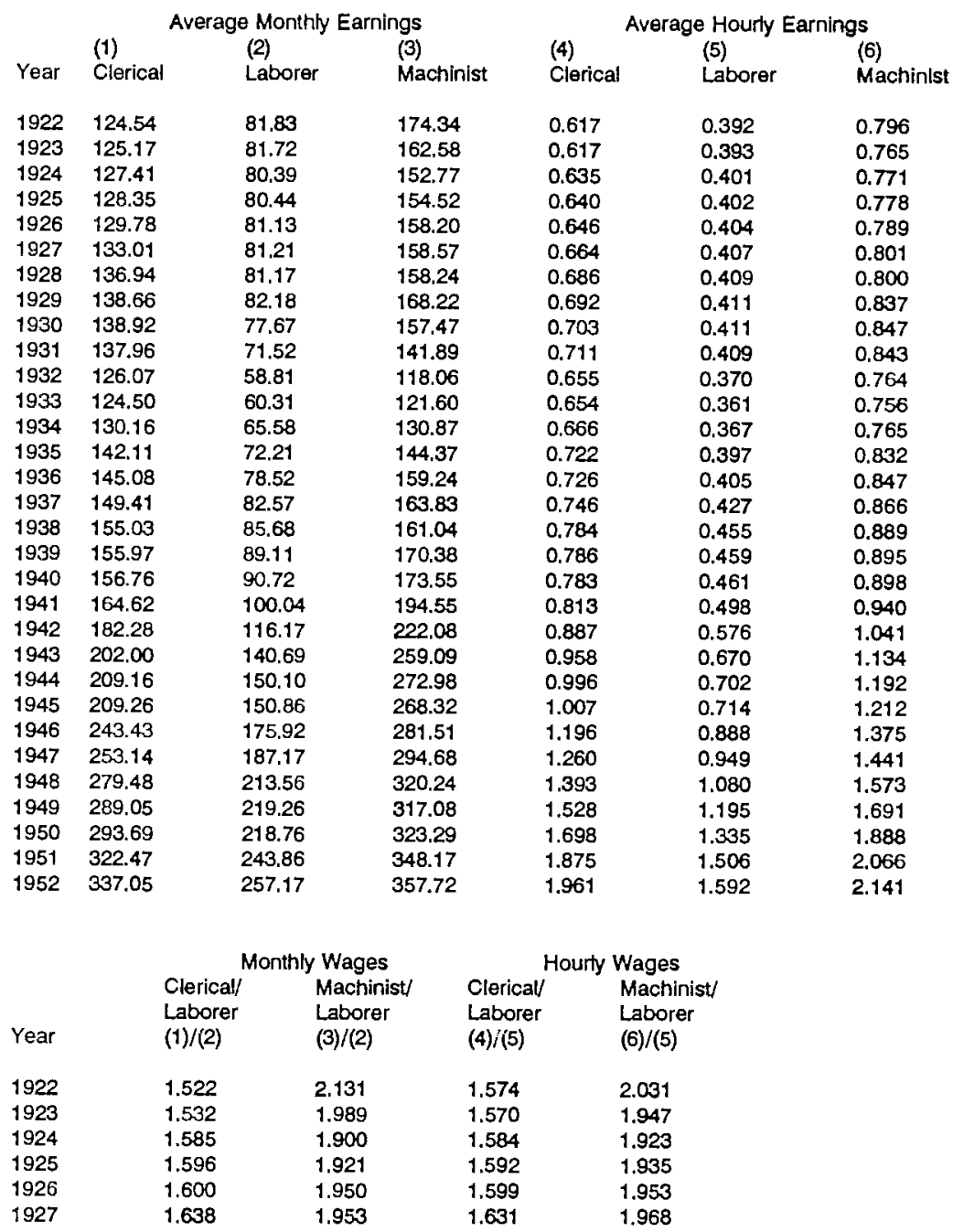




$\begin{array}{lllll}1928 & 1.687 & 1.949 & 1.677 & 1.955 \\ 1929 & 1.687 & 2.047 & 1.684 & 2.036 \\ 1930 & 1.789 & 2.027 & 1.710 & 2.061 \\ 1931 & 1.929 & 1.984 & 1.738 & 2.061 \\ 1932 & 2.144 & 2.007 & 1.770 & 2.065 \\ 1933 & 2.064 & 2.016 & 1.812 & 2.094 \\ 1934 & 1.985 & 1.996 & 1.815 & 2.084 \\ 1935 & 1.968 & 1.999 & 1.819 & 2.096 \\ 1936 & 1.848 & 2.028 & 1.793 & 2.091 \\ 1937 & 1.809 & 1.984 & 1.747 & 2.028 \\ 1938 & 1.809 & 1.880 & 1.723 & 1.954 \\ 1939 & 1.750 & 1.912 & 1.712 & 1.950 \\ 1940 & 1.728 & 1.913 & 1.698 & 1.948 \\ 1941 & 1.646 & 1.945 & 1.633 & 1.888 \\ 1942 & 1.569 & 1.912 & 1.540 & 1.807 \\ 1943 & 1.436 & 1.842 & 1.430 & 1.693 \\ 1944 & 1.393 & 1.819 & 1.419 & 1.698 \\ 1945 & 1.387 & 1.779 & 1.410 & 1.697 \\ 1946 & 1.384 & 1.600 & 1.347 & 1.548 \\ 1947 & 1.352 & 1.574 & 1.328 & 1.518 \\ 1948 & 1.309 & 1.500 & 1.290 & 1.456 \\ 1949 & 1.318 & 1.446 & 1.279 & 1.415 \\ 1950 & 1.343 & 1.478 & 1.272 & 1.414 \\ 1951 & 1.322 & 1.428 & 1.245 & 1.372 \\ 1952 & 1.311 & 1.391 & 1.232 & 1.345\end{array}$

\begin{tabular}{|c|c|c|c|}
\hline Year & Clerk & Laborer & Machinist \\
\hline 1922 & 201.8 & 209.8 & 219.0 \\
\hline 1923 & 202.9 & 207.9 & 212.5 \\
\hline 1924 & 200.6 & 200.5 & 198.1 \\
\hline 1925 & 200.5 & 200.1 & 198.6 \\
\hline 1926 & 200.9 & 200.8 & 200.5 \\
\hline 1927 & 200.3 & 199.5 & 198.0 \\
\hline 1928 & 199.6 & 198.5 & 197.8 \\
\hline 1929 & 200.4 & 200.0 & 201.0 \\
\hline 1930 & 197.6 & 189.0 & 185.9 \\
\hline 1931 & 194.0 & 174.9 & 168.3 \\
\hline 1932 & 192.5 & 158.9 & 154.5 \\
\hline 1933 & 190.4 & 167.1 & 160.8 \\
\hline 1934 & 195.4 & 178.7 & 171.1 \\
\hline 1935 & 196.8 & 181.9 & 173.5 \\
\hline 1936 & 199.8 & 193.9 & 188.0 \\
\hline 1937 & 200.3 & 193.4 & 189.2 \\
\hline 1938 & 197.7 & 188.3 & 181.1 \\
\hline 1939 & 198.4 & 194.1 & 190.4 \\
\hline 1940 & 200.2 & 196.8 & 193.3 \\
\hline 1941 & 202.5 & 200.9 & 204.0 \\
\hline 1942 & 205.5 & 201.7 & 213.3 \\
\hline 1943 & 210.9 & 210.0 & 228.5 \\
\hline
\end{tabular}




$\begin{array}{llll}1944 & 210.0 & 213.8 & 229.0 \\ 1945 & 207.8 & 211.3 & 221.4 \\ 1946 & 203.5 & 198.1 & 204.7 \\ 1947 & 200.9 & 197.2 & 204.5 \\ 1948 & 200.6 & 197.7 & 203.6 \\ 1949 & 189.2 & 183.5 & 187.5 \\ 1950 & 173.0 & 163.9 & 171.2 \\ 1951 & 172.0 & 161.9 & 168.5 \\ 1952 & 171.9 & 161.5 & 167.1\end{array}$

Sources: U.S. Interstate Commerce Commission, Wage Statistics of Class I Railroads in the United States (1922 to 1952). 


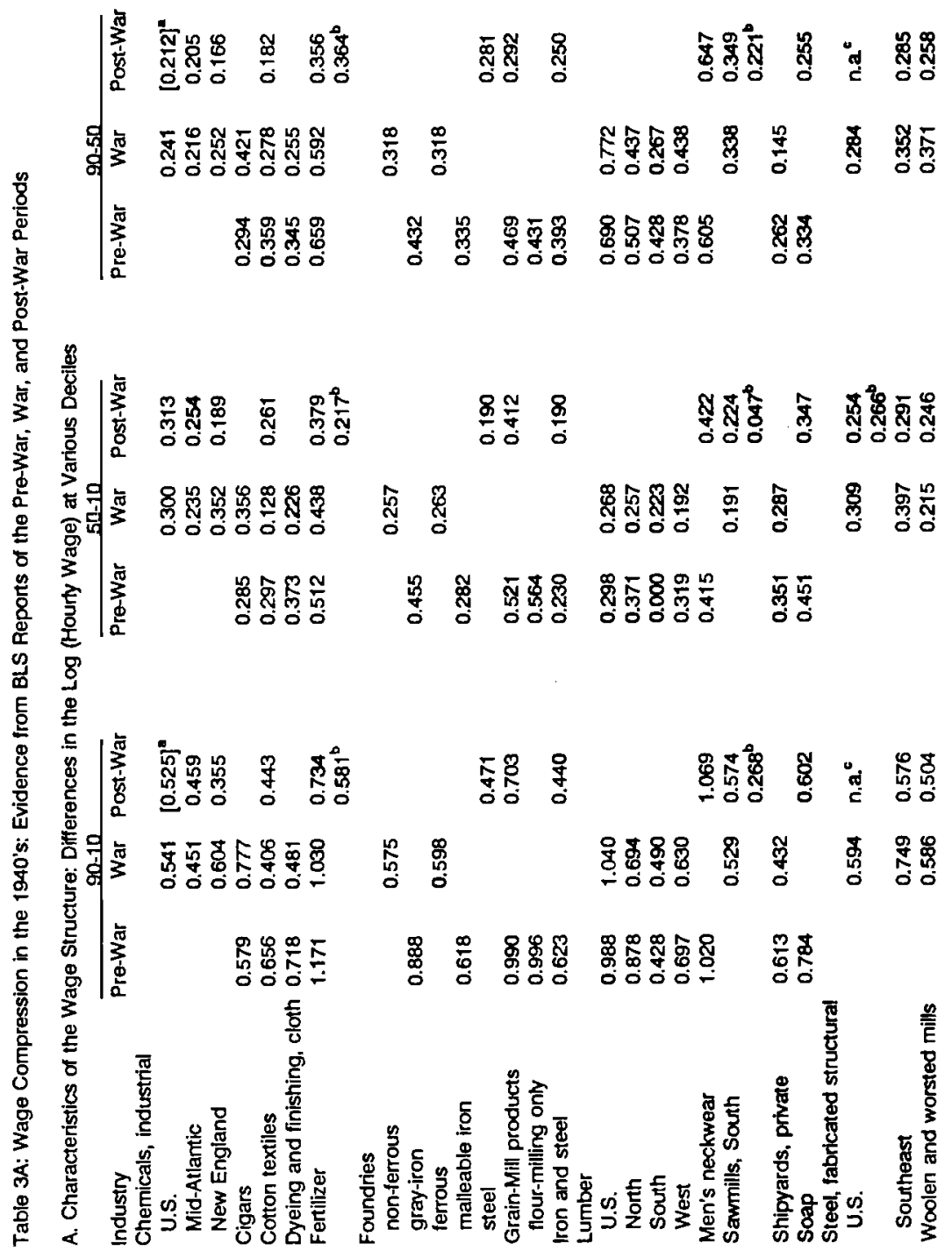




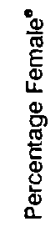

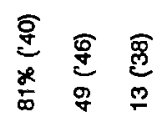

言寒

商

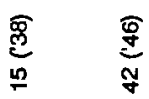

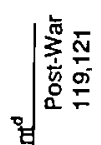

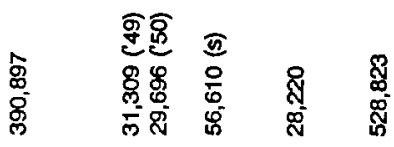

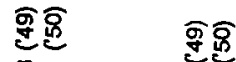

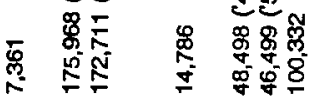

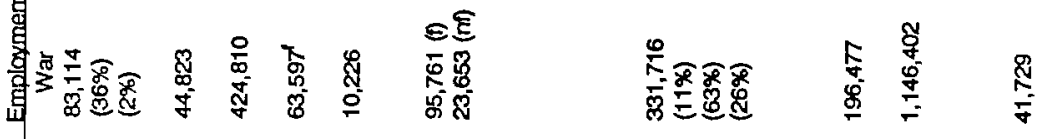

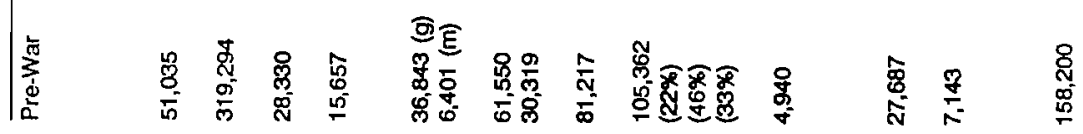

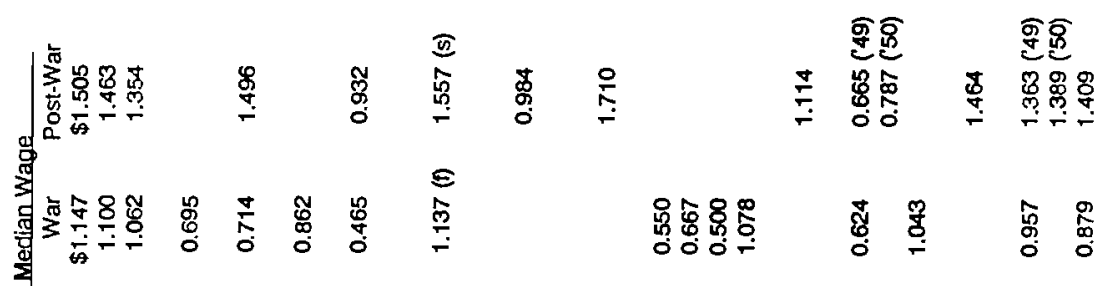

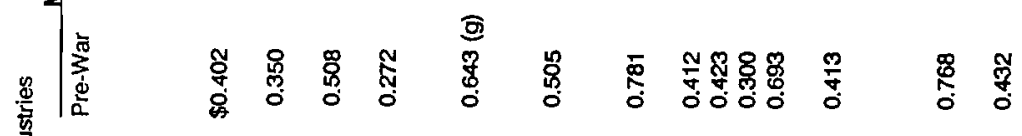

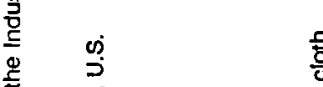

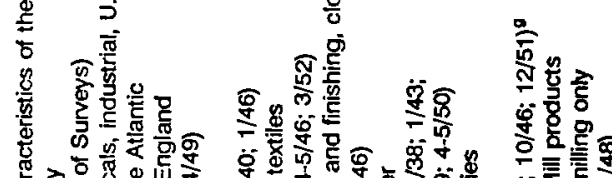

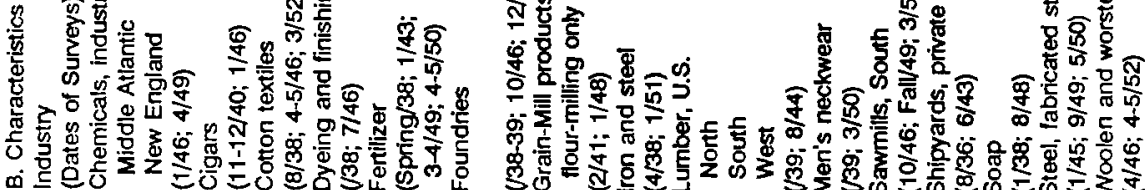

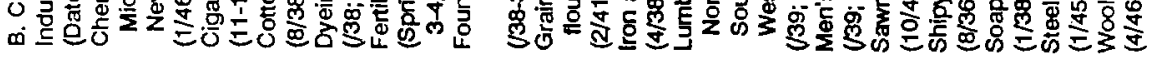


- The top bracket of the hourty wage distribution included $14.6 \%$ of the employees. This calculation assumes that $8 \%$ of employees were In the $\$ 1,80$ to $\$ 1.90$ bracket and probably produces upper bounds to the distribution measures used here.

The second figure for the post-war period refers to the second survey, conducted after the passage of the 1950 minimum wage. See this table, part B for survey dates.

"The top bracket is too large to produce a meaningtul wage at the 9oth percentile.

d Percentages in parentheses in the employment heading give the percentage of total employment in the region.

- Percentage female is given only for industries having data on female employment in the BLS reports. Those that did not mention female employment had a very small percentage female. Numbers in parentheses are the date of the survey.

The 1938 survey included cotton, rayon, and silk, while that for 1946 also included linen, woolen, and worsted.

- Gray-iron $(\mathrm{g})$ and malieable-iron $(\mathrm{m})$ foundries were surveyed for $1938 / 39$, ferrous $(\mathrm{f})$ and nonferrous (nf) for October 1946, and steei (s) in December 1951.

Notes and Sources: Unless noted otherwise, covered employees are wage and salary workers, and wages are given by straight-time average hourty earnings. Linear interpolation was used to estimate wages at the various deciles. All references are from the Monthly Labor Review.

Chemicals, industrial:

"Wage Structure of the Industrial Chemical Industry January 1946," (Nov. 1946): 745-49.

"Wages in Selected Chemical Industries, April 1949," (Oct. 1949): 397.

The 1949 survey covered workers in plastics, while that for 1946 did not.

Cigars:

"Hours and Eamings in the Cigar Industry, 1940," (Dec. 1941): 1522.

Wage Structure of the Cigar Manufacturing Industry, January 1946," (Jan. 1947): 47.

Cotton textiles:

"Average Hourty Eamings in Cotton-Goods Industry, 1937," (Apr. 1938): 978.

"Wage Structure in Cotton-Goods Manufacture," (Dec. 1938): 1244.

"Hours and Earnings in Manufacture of Cotton Goods, Sept. 1940 and April 1941," (Dec. 1941): 1510.

Wage Structure in Cotton-Textile Mills, April-May, 1946," (Feb. 1947): 455.

"Economic Probiems and Wage Structure in Cotton Textiles," by S. Shapiro and C. Rubenstein, (Aug. 1952): 146.

Cotton textiles has sufficient data to produce a more detailed set of estimates:

1934

Apr. 1937

1938

Sept. 1940

Apr. 1941

1946

1952

(post-war, 40 cent minimum wage)

(post-war, 75 cent minimum wage)
90-10

50-10

0.534

0.647

0.656

0.468

0.503

0.406

0.443
0.168

0.286

0.297

0.108

0.142

0.128

0.261
90-50

0.366

0.361

0.357

0.360

0.361

0.278

0.182

Dyeing and finishing, cloth:

"Hourly Earnings in Dyeing and Finishing of Cotton, Rayon, and Silk," (Jan, 1940): 186.

"Wage Structure of Textile Dyeing and Finishing Industry, July 1946," (June 1947): 1035.

See footnote $f$.

Fertilizer:

Wages and Hours in the Fertilizer Industry, 1938," (Mar. 1939): 673.

"Hours and Eamings in the Fertilizer Industry," (Aug. 1943): 342.

"75-Cent Minimum Wage: Effects on Fertilizer Industry," (Jan. 1951): 34.

Foundries: 
"Earnings in Gray-Iron and Malleable-Iron Foundries, 1938-39," (Nov. 1940): 1208.

"Wages of Foundry Workers, October 1946," (Aug. 1947): 181.

"Steel Foundries," August 1952: 179.

Grain-Mill products:

"Earnings in the Grain-Mill Products Industries, 1941," (Apr. 1942): 1014

"Grain Milling Industry: Wage Structure, January 1948," (July 1948): 30.

It is likely that the $194 t$ survey included animal feed while that for 1948 did not. For this reason, the data for 1941 are also giver for flour-milling only.

Iron and steel:

"Earnings and Hours in the Iron and Steel Industry, April 1938,"(Aug. 1940): 432.

"Basic Iron and Steel Industry Wage Structure, January 1951," (Jarı. 1952): 159.

Lumber:

"Hourly Earnings in the Lumber and Timber Products Industry," (July 1941): 195.

"Wages in the Basic Lumber Industry, 1944," (Oct. 1945): 766.

Men's neckwear:

"Earnings and Hours in Men's Neckwear Industry, 1939," (Feb. 1940): 415.

"Wage Structure in Neckwear Industry, March 1950," (Sept. 1950): 358.

Sawmills:

"Wages in Sawmills in the South, September-October 1946," (June 1947): 1030.

"Effects of Minimum Wage in Southern Sawmills: Analysis of Wage Structure Changes between the Fall of 1949 and March 1950 Arising from Application of the 75-cent Minimum Wage," (Sept. 1950): 314.

Shipyards, private:

"Earnings and Hours of Labor in Private Shipyards, 1936 and 1937," (Sept. 1938): 504.

"Basic Wage Rates in Private Shipyards, June 1943," (Aug. 1944): 393.

For comparability across the two years, the hourty basic rate was used, rather than the average hourty rate. Only the private shipyards covered by the Stabilization Agreements $(90 \%$ of shipbuilding employees were hired by such firms) are included in the 1943 wage distribution results.

Soap:

"Earnings and Hours in the Soap Industry, January 1938," (June 1938): 1425.

"Soap and Glycerin Manufacture: Earnings in August 1948," (Apr. 1949): 418.

Steel, fabricated structural:

Wage Structure of the Fabricated Structural-Steel Industry, January 1945," (Apr. 1946): 624.

"Structural Steel Fabrication: Earnings, 1949 and 1950," (May 1951): 365.

The Southeast region is the only one for which the top portion of the wage distribution allowed the calculation of the wage at the 9oth percentile.

Woolen and worsted industry:

Wage Structure in Woolen and Worsted Industry, April 1946," (Mar, 1947): 463.

Woolen and Worsted Textiles Eamings in April-May 1952," (Oct. 1952): 404. 
Figure IA

Clerk Wages Relative to Unskilled and Laborer Wages, Males: 1922 to 1952

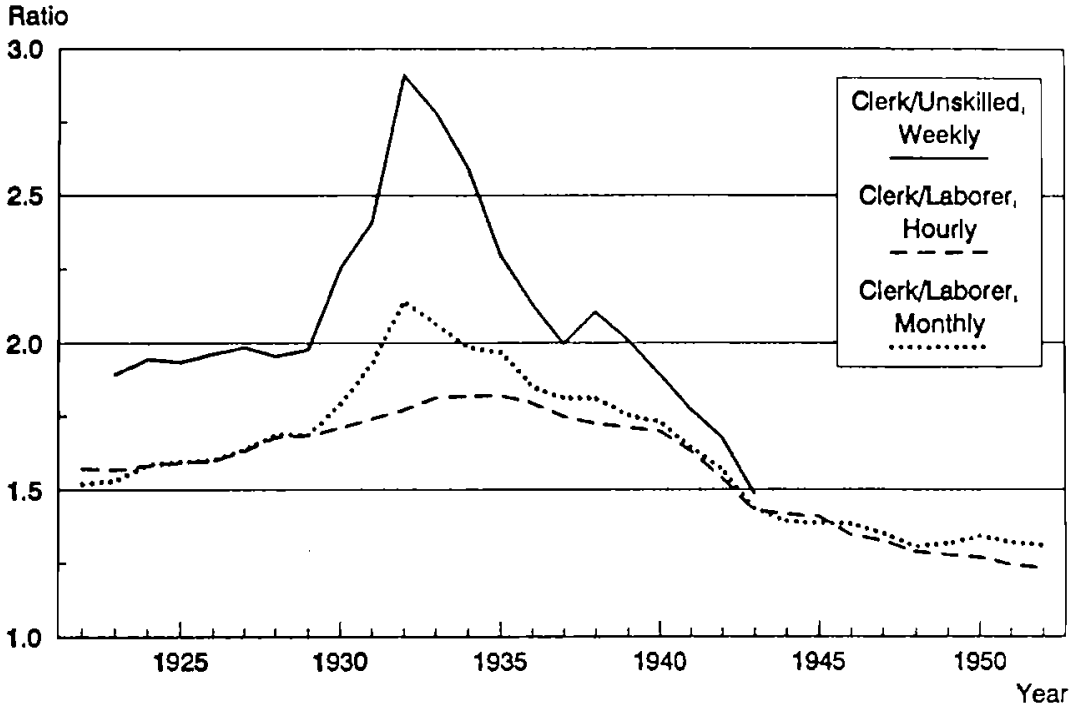

Source: Table 8, columns (4) and (6).

Notes: The weekly series for clerks is for male office workers in New York State factories, and the corresponding series for the unskilled refers to production workers in 25 industries. The hourly and monthly series are for workers on class-I steam railroads. 
Figure llA

Ratlos of the Wages of Clerks and Machinists to those of Laborers, Males, Cless-I Steam Railroads; $1922-1952$

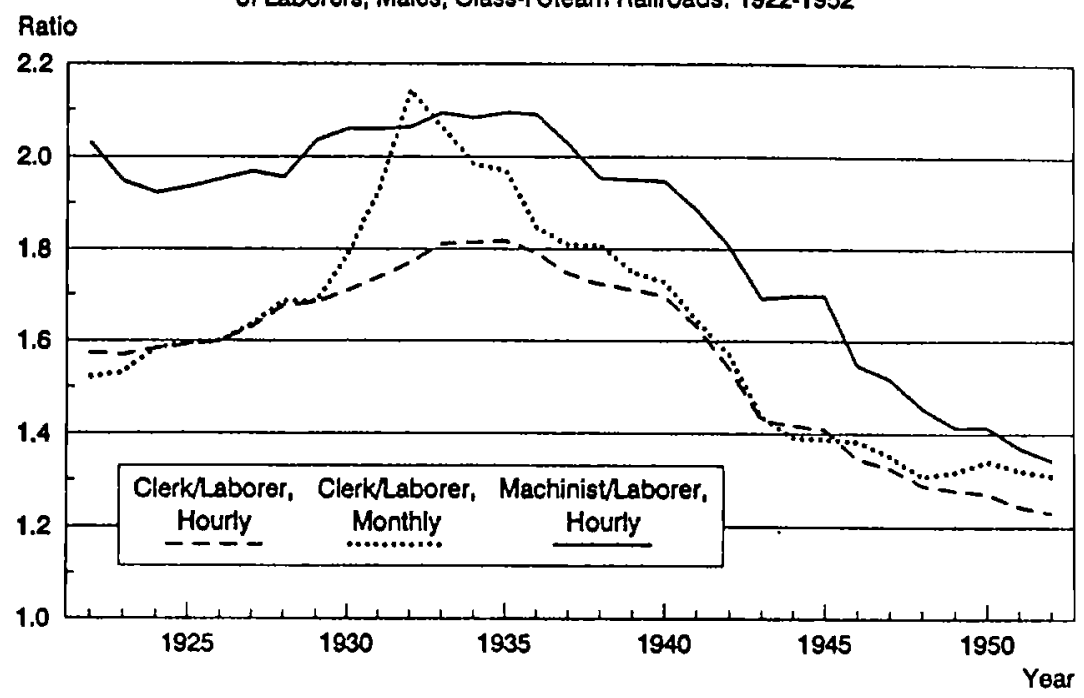

Source: Table 8, columns (4) and (5). Also Table 2A. 
Figure IILA

Skill Ratios for Male Production Workers and Machinists, 1922 to 1952

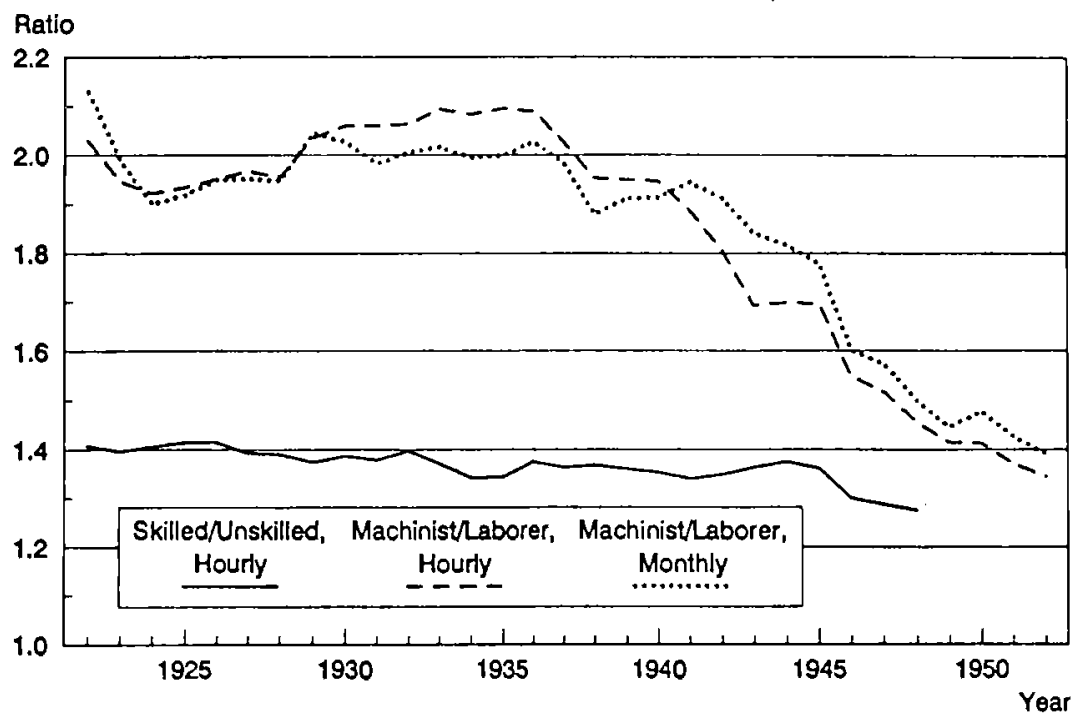

Sources: Table 8, column (1), and Table 2A

Notes: The hourly skilled and unskilled series are for production workers in 25 industries and come from the National Industrial Conference Board data. The machirist and laborer series are for workers on class-I steam railroads. 


\section{Figure NA}

Clerk Wages Relative to Unskilled and

\section{Ratio}

Operative Wages, Males and Females: 1923 to 1943

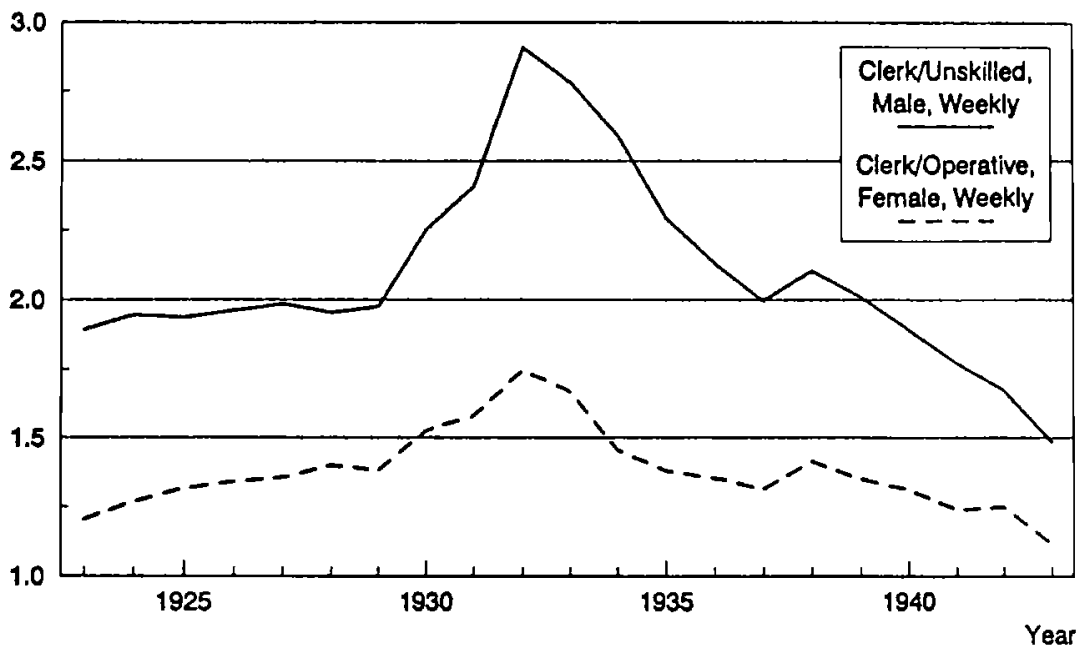

Source: Table 1A, column (4).

Notes: The two clerk series are for office workers in New York State factories, and the corresponding series for the unskilled and operatives refer to production workers in 25 industries (from National Industrial Conference Board data). The data for female clerks come from the same sources as do that for male clerks, but the series is not given in Table 1A. 